\title{
Gramsci'nin Hegemonya Kuramı Bağlamında Nükleer Karşıtı Hareketin Milliyet Gazetesindeki Temsiliyeti (11 Ocak 1999-25 Temmuz 2000)
}

\author{
MEHMET ÖZÇAĞLAYAN \\ mehmet.ozcaglayan@marmara.edu.tr \\ ORCID ID: 0000-0001-6459-8054
}

\author{
FILIZ YAVUZ ÇAKICI \\ filizyvz@gmail.com \\ ORCID ID: 0000-0001-5837-242X
}

Öz: Nükleer enerji hükümetler üstü bir konu; bir devlet politikasıdır. Dolayısıyla siyasi görüşleri farklı olsa da 1970'lerden itibaren hükümetler eliyle nükleer enerjiye geçiş sürecinde ısrar edilmiştir. Öte yandan nükleer enerji, başta yöre insanı olmak üzere tüm halkın yaşamını etkileyecek nitelikte bir konudur. Bu yüzden sürecin başarıya ulaşması, halkın, Türkiyènin nükleer enerjiye geçişine rıza göstermesine bağlıdır. Medya ise halkın rızasını sağlamak için egemen söylemi yeniden ve yeniden üreterek yayan bir kurum olarak karşımıza çıkmaktadır. Kavramsal temelini Gramscinin hegemonya kuramının oluşturduğu bu makalede, Teun van Dijk'in Eleştirel Söylem Analizi disiplininden yararlanılarak, Bülent Ecevit'in başbakanlık koltuğuna oturduğu 11 Ocak 1999 ile Akkuyu nükleer santral ihalesini iptal ederek nükleer enerji konusunu rafa kaldırdığı 25 Temmuz 2000 tarihleri arasında, nükleer karşıtı hareketin Milliyet gazetesindeki temsiliyetine odaklanılmış ve bu süreçte, Milliyet gazetesinin nükleer enerjiyle ilgili egemen söylemi üretip üretmediği ve topluma karşı sorumluluğunu ne kadar ve nasıl yerine getirdiği değerlendirilmeye çalışılmıştır.

Anahtar kelimeler: Hegemonya, Eleştirel söylem analizi, Nükleer enerji, Nükleer karşıtı hareket, Milliyet Gazetesi..

\section{Giriş}

Nükleer enerji, sanıldığının aksine sadece enerji politikalarını ilgilendiren teknolojik bir konu değil; tüm dünyada olduğu gibi Türkiye'de de siyasi bir tercihtir. ${ }^{1}$ Üstelik çalışmanın odaklandığı dönemin başbakanı Bülent Ecevit’in nükleer enerji için sarf ettiği "Bu hükümetin sorunu değil devletin sorunudur."2 ifadelerinden, 1970’lerden bu yana kurulan hemen her hükümetin nükleer enerji için çabalamasından yola çıkarak bu tercihin sadece hükümetlere ait olmadığını, aslen devlete ait olduğunu söy-

* Doç. Dr., Marmara Üniversitesi, İletişim Fakültesi, Gazetecilik Bölümü.

${ }^{* *}$ Dr.

1 Tolga Yarman, Geçmişte ve Bugün Nükleer Enerji Tartışması, İstanbul: Okan Üniversitesi Yayınları, 2010, s.59.

2 Önder Yılmaz, "Nükleer santrale 'evet”, Milliyet Gazetesi, 3 Aralık 1999, s.11. 
lemek mümkündür.

Ekonomik istikrarsızlık ile anılan ${ }^{3}$ dahası ekonomik ve politik olarak kayıp 10 yıl

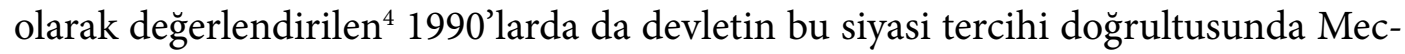
lis’teki partilerin neredeyse sırayla yer aldığ kısa süreli koalisyon hükümetleri eliyle yürütülen nükleer çalışmalar hız kazanmış, bu da nükleer karşıtı seslerin yükselmesini beraberinde getirmiştir. Meslek odaları, sendikalar, Meclis dışındaki çeşitli sosyalist partiler ve çevre örgütleri de muhalefet unsurları olarak nükleer karşıtllğg üzerinden bir araya gelmiştir.

Bu 10 yıllık süreç içinde özellikle 1999-2000 yılları dikkat çekicidir: Sosyal demokrasiden yana olan Demokratik Sol Parti’nin (DSP) 11 Ocak 1999'da tek başına iktidara gelmesiyle DSP genel başkanı Bülent Ecevit başbakanlık koltuğuna oturmuş ve 28 Mayıs 1999'da DSP'nin merkez sağda yer alan Anavatan Partisi (ANAP) ve Türk milliyetçisi Milliyetçi Hareket Partisi (MHP) ile kurduğu koalisyon hükümeti kapsamında görevine devam etmiştir. Başbakan Ecevit nükleer enerji konusunda zaman zaman çekincelerini ve kararsızlı̆̆ını ifade etmiş ancak bu, -koalisyon ortaklarının da payıyla- onun döneminde ülkedeki nükleer çalışmaların hız kazanmasını engellememiştir.

Bu noktada devlet açısından önemli olan, Ecevit'in nükleer enerjiye karşı çekinceli tutumunu halka mümkün olduğunca az yansıtarak gidermeye çalı̧̧mak ve 26 Nisan 1986 yllında meydana gelen Çernobil nükleer kazasının Türkiye’ye etkilerini hala hafızasında taze bir şekilde tutan halkın, yaşamının her alanını etkileyecek nükleer enerjiye geçiş çalışmalarına dair rızasını almaktır. Bunun için en önemli araçların başında medya gelmektedir.

Van Dijk, kamusal iletişimde hayati rol oynayan gazete metinlerinin, televizyon haberlerine göre daha çok akılda kaldığını üstelik, bunların basılı metinler arasında en etkilileri olmasa da en yaygını olduğunu belirtmektedir. ${ }^{5} \mathrm{Bu}$ yüzden çalışma alanı olarak bir gazete; dönemin önemli yazılı basın organlarından biri olan Milliyet gazetesi seçilmiştir. Ancak çalışmanın Milliyet gazetesine odaklanmasının asıl nedeni, her ne kadar çekincelerini dile getirmiş olsa da bir süre sonra nükleer enerjiye geçiş için ikna olduğunu açıklayan başbakan Bülent Ecevit'in, 25 Temmuz'da sürpriz bir biçimde Akkuyu nükleer santralinin ihalesini iptal etmesi ve nükleer enerji konusunu rafa kaldırması üzerine gazetenin yayımladığı bir haberdir. "İptale Milliyet katkısı" başlıklı bu haberin spotunda şöyle denilmektedir: "Nükleer santralın iptaline giden sürece Milliyet damgasını vurdu. Gerek manşetleri, gerekse köşe yazarlarıyla nükleer tehlikeye dikkat çekmek için toplumu uyarma görevini yerini getirdi.”

3 Erinç Yeldan, “Türkiye Ekonomisi: Krizin Yapısal Dayanakları”, Birikim Dergisi, 144 (2001), s.8.

4 Cenk Sidar, “Türkiye 90'lara dönmüyor: Bu zihniyetin bizi taşıdığı yer çok daha karanlık!”, 3 Ağustos 2005, erişim, 8 Ağustos, 2018, http://www.diken.com.tr/turkiye-90lara-donmuyor-bu-zihniyetin-bizi-tasidigi-yercok-daha-karanlik/.

5 T.A. van Dijk, “Söylemin yapıları ve iktidarın yapıları”, Medya, İktidar, İdeoloji, çev., Mehmet Küçük, Ankara: Bilim ve Sanat, 2005, s. 349. 


\section{iptale Milliygt katkısı}

Nükleer santralın iptaline giden sürece Milliyet damgasını vurdu. Gerek mansetleri, gerekse köșe yazarlanyla nükleer tehlikeye dikkat çekerek toplumu uyarma görevini yerine getirdi
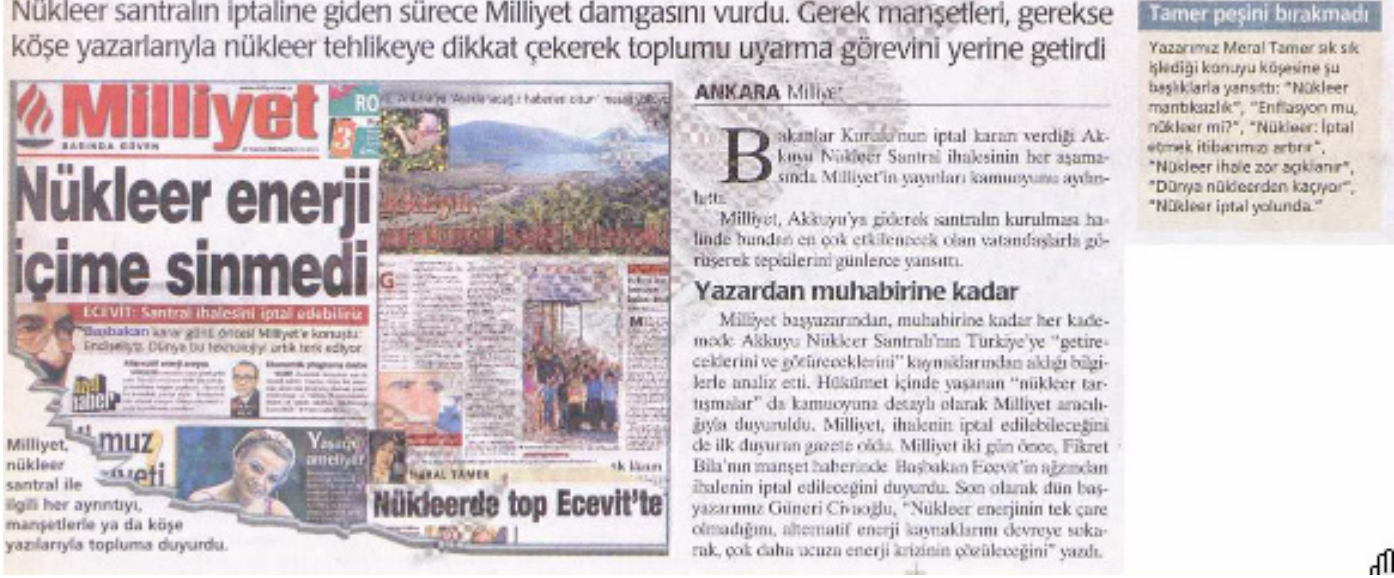

Şekil 1. 26 Temmuz 2000, sayfa 4.

Kendini yakın hissettiği farklı siyasetçileri ya da partileri dönemsel olarak desteklemekten kaçınmasa da, Milliyet gazetesinin genel yayın politikasında sosyal demokrat bir çizgi izlediği söylenebilir. ${ }^{6} \mathrm{Bu}$ anlamda sosyal demokrat bir başbakan eliyle sürdürülen nükleer enerjiye geçiş sürecine, bu süreç devam ederken sosyal demokrat Milliyet gazetesi tarafından karşı çıkıldığg ve gazetenin nükleer ihalenin iptaline katkısının olduğu iddiası dikkate değerdir. Aslında Başbakan Ecevit’in nükleer enerji konusunda çekinceli olduğu düşünüldüğünde sosyal demokrat bir gazetenin de nükleer enerjiye karşı olması ve yayınlarıyla nükleer enerjiye dair toplumu uyardığı iddiası akla yatkındır. Peki, bu iddia doğru mudur? Milliyet gazetesi gerçekten de haberlerinde ve köşe yazılarında halkın rızasını sağlamak için egemen söylemi yeniden üretmemiş midir? Ya da yayınlarıyla nükleer enerji konusundaki devlet politikasına karşı mı çıkmıştır? Gerçekten de nükleer karşıtı seslere yer vererek toplumu uyarmış mıdır? Çalışma, bu süreçteki nükleer karşıtı seslerin ana akımda yer alan sosyal demokrat bir gazetedeki yansımasına odaklanacak ve gazetenin iddiasını van Dijk'in Eleştirel Söylem Analizi disiplini çerçevesinden sorgulayacaktır.

Birinci nükleer santralini Akkuyu'ya kurmak için Rusya ile, ikinci nükleer santralini Sinop’a kurmak için ise Japonya ile hükümetler arası anlaşmalara imza atmış olan Türkiye’nin bulunduğu nükleer eşikte, Milliyet gazetesi üzerinden nükleer enerji konusunda ana akımda yer alan yazılı basının gerçekten toplum yararına mı çalıştığı, yoksa egemen düşünceyi yeniden üreterek halka yayma görevini mi üstlendiğini anlamak açısından oldukça önem verilen bu çalışmanın, daha geniş kapsamda üretilen bir doktora tezinde ele aldığı konu ve bağlam itibariyle gazetecilik alanında bir ilk olduğunu belirtmek de yararlı olacaktır.

6 Aslı Çakır, Pınar Gürleyen ve Faik Uyanık. "Milliyet Gazetesi”, Haber Analizi ve Arşiv incelemeleriyle Türkiye'de Dokuz Gazete, haz., Şengül Özerkan, Ankara: Nobel Yayın Dağıtım, 2009, s.109. 


\section{Kavramsal Çerçeve}

Gramsci'nin hegemonya kuramı ve kuramın medyaya uyarlanmış halinin belirlediği çalışmanın kavramsal çerçevesini, A. Teun van Dijk'in sosyobilişsel eleştirel söylem analizi yöntemi oluşturacaktır.

“Bir toplumsal grubun baskınlığı, 'egemenlik' olarak ve 'entelektüel moral yönetimi' olarak kendini iki biçimde gösterir. Bir toplumsal grup, 'temizleme' ya da boyun eğdirme amacını güttüğü hasım gruplar üzerinde, gereğinde silah gücüyle de olsa, egemenliğini uygular ve kendine yakın ya da bağlaşık olan grupları yönetir. Bir toplumsal grup, hükümet erkliğini fethetmeden önce de yönetici olabilir ve hatta olmalıdır da (ve erkliğin kendisinin fethi için başlıca koşullarından biri de işte budur.) Sonra erkliği kullandığ 1 zaman ve onun elinde sıkı sıkıya da tutuyorsa, egemen grup durumuna gelir, ama yönetici grup olmayı da sürdürmelidir."

Yukarıda alıntılandığı üzere Gramsci, toplumun büyük kesiminin elit bir azınlık tarafından nasıl yönetildiğiyle ilgilenir ve sorunun yanıtını hegemonya kavramı ile açıllar. Hegemonya, aslında V. I. Lenin tarafından yönetici sınıf olarak proletarya üzerine geliştirilen teze ve yönetim pratiğine karşılık düşer ve proletaryanın egemen olduğunda karşıt gruplar üzerinde kaçınılmaz olarak uygulayacağ eder. Oysa Gramsci, zorlamanın yanı sıra bu kavrama 'rıza'yı da dahil ederek Lenin'in tezini geliştirmiş, hegemonyanın anlamını liberal ve faşist devletleri de içine alacak şekilde genişletmiştir. ${ }^{8}$

Gramsci devleti, gücü temsilen politik toplumun ve rızayı temsilen sivil toplumun birlikteliği ile tanımlar. ${ }^{9}$ Başka bir deyişle egemen ya da hegemonya sahibi olmak için ekonomik ve politik güç yeterli değildir, bağımlı grupların rızasına da ihtiyaç vardır. ${ }^{10}$ Hall, hegemonyanın güç ve rızanın birleşimine dayandığını söyler, ancak ekler: "Liberal-kapitalist devlette 'zorunlu kuşandığı zırh'ın berisinde işleyen rıza normal olarak başı çeker" ${ }^{11}$ Dolayısıyla hegemonya sadece güç ya da zor kullanarak elde edilmez, hegemonya kurmak için rızaya da ihtiyaç vardır ki; rıza, hegemonyanın kuruluşunun temel göstergelerindendir.

"Gramsci, iki yüz yılı aşan yayılma ve sağlamlaşma sürecinde kapitalizmin liderliğini okullar ve üniversiteler, kiliseler, edebiyat, felsefe, medya ve şirket ideolojileri gibi enformasyon birimleri aracılığıyla sürdürdüğünü ve örgütlediğini ileri sürmüştür." ${ }^{2}$

7 Antonio Gramsci, Hapishane Defterleri: Tarih, Politika, Felsefe ve Kültür Sorunları üzerine Seçmeler, çev., Kenan Somer, İstanbul: Onur Yayınları, 1986, s.14.

8Gilbert Moget, "Hegemonya”, Hapishane Defterleri: Tarih, Politika, Felsefe ve Kültür Sorunları üzerine Seçmeler, çev., Kenan Somer, İstanbul: Onur Yayınları, 1986, s.73, 74.

9 Gramsci, Hapishane Defterleri, s.186.

10 Karacasulu, Nilüfer. “Hegemonik Düzen Tartışmaları ve Eleştirel Görüşler”, Dokuz Eylül Üniversitesi Sosyal Bilimler Enstitüsü Dergisi, 11/4 (2009), s.60.

11 Stuart Hall, “Kültür, Medya ve 'İdeolojik Etki”, Medya, İktidar, İdeoloji, çev., Mehmet Küçük, Ankara: Bilim ve Sanat, 2005, s.214.

12 John D.H. Downing, Radikal Medya: Isyancıların İletişimi ve Toplumsal Hareketler, haz., Ülkü Doğanay, Ankara: İmge, 2017, s.44, 45. 
Başka bir deyişle Gramsci’nin hegemonya kuramına göre elit azınlık devlete, onun organlarına ve kitle iletişim araçlarına sahiptir ve bu araçlar sayesinde çoğunluk üzerinde kontrolünü sağlamaktadır. Hegemonya topluma yön veren sinıfın dünya görüşüdür. Başka bir deyişle, toplumu yöneten elit azınlığın toplumun diğer kesimleri üzerindeki ideolojik ve kültürel kontrolüdür. Bu ideolojik ve kültürel hakimiyet inançları, ahlak kurallarını ve egemen sınıfın topluma egemen olmasını istediği tüm değerler sistemini aile, okul, kilise gibi tüm toplumsal kuruluşlar ve bu kuruluşlar üzerinden hayatın her alanına yayarak kurulmaktadır. ${ }^{13}$

Öyleyse seçkin azınlığın çıkarlarını koruyacak şekilde onun dünya görüşünü, felsefesini, kültürel ve ahlaki değerlerini bağlı bulunan grupların rızasına dayalı olarak kimler yaymaktadır? Gramsci bu işlevi yerine getiren din görevlileri, öğretmenler ve gazeteciler gibi önemli unsurlardan söz etmekte ve onları organik aydın olarak tanımlamaktadır. ${ }^{14}$ Organik aydınlar, işçi sınıfında sınıf bilincinin gelişmesini önlemek için tüccar, sanayici ve küçük burjuva sınıflarının ifadesi olan milliyetçi sağ görüşlerin sağduyu ve his haline getirilmesini sağlayarak bunları, toplumun değer yargısı haline getirir; bu değer yargılarına alternatif olabilecek düşünceleri ise bazen görmezden gelerek, bazen açıkça onlara karşı savaş açarak, bazen de bu düşünceyi savunanları itibarsızlaştırarak yok etmeye çalışırlar. ${ }^{15}$ Bunu sistematik olarak yaparlar zira egemen sınıfın iktidarının sürdürülmesi için hegemonyanın devam etmesi ve yeniden ve yeniden üretilmesi gerekmektedir.

Hegemonyanın sistematik olarak yeniden ve yeniden üretildiği kurumlar arasında medya da bulunmaktadır. Hatta medya, kapitalist toplumlarda çoğunluğun rızasını sağlamaya yardımcı olan kurumlarının başında gelmektedir. ${ }^{16}$

“Gramsci’nin hegemonya kavramı (ve kuramı) medyaya uygulandığında görülür ki medya, okuyuculara egemen sınıfın değerlerini aktaran bir araçtır. Medya genel olarak egemen yapıya ve egemen değerlere karşı olan ve bunların içerisinde tehlikeye atan her türlü olaya karşıdır. Bunlar içerisinde işçi sınıfina ve onun ideolojisine yakın olma ihtimali bulunan sendikalar ve bunların egemen düzen için bir tehdit oluşturan eylemlerine (yani grevler), toplumsal düzeni tehdit eden protestoculara ve gösteri yürüyüşü yapanlara, Marksizm’e, solculara, çevrecilere ve farklı cinsel kimliklere karşıdır. Bunun yanında, kapitalist üretim ilişkileri doğal düzen kabul edilir. Kapitalist girişim, kar ve yöneticilerin her türlü girişimi ve uygulamaları sağduyu ve toplumun çıkarı olarak sunulur. Medyada haber değeri olacak olay ve olgular hep egemen sınıfın bakış açısıyla sunulur. (...) Kitle İletişim Araçları egemen temel değerleri kabul eder ve sağduyuya uygun olarak yani herkesin bildiği bir dünya tasarımı sunar. Sonuç olarak medya egemen değerleri aktararak hegemonyayı yeniden üretir". ${ }^{17}$

Van Dijk medyanın toplumsal iktidar yapılarının üretiminde ve yeniden üretiminde

13 Levent Yaylagül, Kitle İletişim Kuramları; Egemen ve Eleştirel Yaklaşımlar, Ankara: Dipnot Yayınları, 2006, s.97. 14 Gramsci, Hapishane Defterleri, s.315.

15 Yaylagül, Kitle İletişim, s.109-113.

16 Banu Dağtaş, “İngiliz Kültürel Çalışmalarında İdeoloji”, Kurgu Dergisi, 16 (1999): 335-357. s.343.

17 Yaylagül, Kitle İletişim Kuramları, s.101. 
kendine ait özerk rolünün altını çizmektedir. "Van Dijk’’n da belirttiği gibi ideolojiler büyük oranda söylem yoluyla edinilir ve söylemi dolaşıma sokan temel kurum kitle iletişim araçlarıdır." ${ }^{18}$ Ona göre medya, seçkinlerin sözcüsü değil, simgesel boyutunu yönettiği toplumsal iktidar yapısının kalıtsal bir parçasıdır. ${ }^{19}$ Ve gerçeği yansıtmamakta ve aslında gizli ya da açıktan, egemen söylemi tekrar ve tekrar üretmektedir. ${ }^{20}$

Bu noktada bir parantez açmakta fayda vardır. Zira, Milliyet gazetesinin ilgili haberinde geçen "toplumu uyarma görevi" teorik olarak toplumsal sorumluluk kuramına referans vermektedir. Medyanın oynaması gereken rolleri ve işlevlerini vurgulayan normatif medya kuramları arasındaki toplumsal sorumluluk kuramı halen gazetecilik mesleğinin kuralları ile etik kodlarını belirlemektedir.

ABD'de ortaya çıkan sosyal sorumluluk kuramı, Hutchins Komisyonu adıyla anılan Basın Özgürlüğü Komisyonu’nun 1947 tarihli raporuna dayanmaktadır. Bu rapor, medyanın kendisine yönelik kapsamlı ve nitel bir eleştiri girişimidir ve kapsamlı ilkelere ve genel doğrulara dayanarak basına 'sorumlu bir özgürlük' çağrısında bulunmaktadır. ${ }^{21}$ Raporla birlikte basın konusundaki vurgu, raporun basını kamu yararına hizmet eden bir kurum olarak tanımlamasıyla özgürlükten sorumluluğa doğru kaymakta; alınması istenen sorumlulukların arasında günün olaylarını ve bu olayların anlamlarını doğru ve kapsayıcı bir biçimde sunma öne çıkmaktadır. ${ }^{22} \mathrm{Ra}$ por, enformasyonun özgür akışına ve düşüncelerin çeşitliğine olan inancı yeniden onaylamakta ve basına sahip olanların ve basını ekonomik ya da siyasal araçlar yoluyla denetleyenlerin düşüncelerinin hakimiyetine giren medyanın tehlikelerine dikkat çekmektedir."23

Ancak rapor medyayı sorumluluk almaya ikna edememiş ve bir grup düşünürün zarif bir çağrısı olarak kalmıştır. ${ }^{24}$ Ta ki 1956 yılına kadar. 1956'da Fred S. Siebert, Theodore Peterson ve Wilbur Schramm tarafindan yazılan "Basının Dört Kuramı" adlı kitap, raporun tespit ve önerilerini "sosyal sorumluluk teorisi" adıyla ortaya koymuştur. ${ }^{25}$

Medya sermayesinin birkaç kişinin elinde toplanması ve medya sahiplerinin de bu gücü kendi ekonomik ve siyasi çıkarları için kullanmaya başlaması, liberal kuramın pratikte ortaya çıkan eksiklikleri olarak addedilmektedir. Bu eksiklikleri gidermek üzere kurgulanan toplumsal sorumluluk kuramı ise liberal kurama pek çok açıdan benzerlik göstermekle birlikte basının, topluma karşı sorumlu olduğu savıyla liberal

18 Hediye Esra Arcan, İnsan Hakları ve Medya: ABD Elit Medyasında Türkiye’ye İlişkin İnsan Hakları Haberlerinde Söylem İnşası; The New York Times Gazetesi Örneği, Doktora Tezi, İstanbul Üniversitesi SBE, 2010, s. 81 .

19 van Dijk, “Söylemin yapıları ve İktidarın Yapıları”, s. 249, 250.

20 Ayşe İnal, Haberi Okumak, İstanbul: Timuçin Yayınları, 1996, s.70, 97.

21 Hanno Hardt, “Eleştirelin’ Geri Dönüşü ve Radikal Muhalefetin Meydan Okuyuşu: Eleştirel Teori, Kültürel Çalışmalar ve Amerikan Kitle İletişim Araştırmaları”, Medya İktidar İdeoloji, çev., Mehmet Küçük, Ankara: Bilim ve Sanat, 2005, s.25-26.

22 Ruhdan Uzun, İletişim Etiği; Sorunlar ve Sorumluluklar, Ankara: Dipnot Yayınları, 2011, s.40.

23 Hardt, “'Eleştirelin’ Geri Dönüşü ve Radikal Muhalefetin Meydan Okuyuşu”, s.25.

24 Hardt, “Eleştirelin' Geri Dönüşü ve Radikal Muhalefetin Meydan Okuyuşu”, s.26.

25 Murat Özgen, Gazetecinin Etik Kimliği, İstanbul: Set-Systems, 2006, s.134. 
kuramdan ayrışmaktadır. Toplumsal sorumluluk kuramının en önemli yanı da işte budur. Medya, bu sorumluluğu yerine getirmeli, toplum da medyadan kaliteli bir hizmet beklemelidir. Bu da ancak "nesnellik", "tarafsız olma" gibi mesleki standartların gerçekleşmesiyle mümkündür. Aksi halde gazetecilik mesleğinin başka çıkarların mücadele alanı haline gelir ki; buna izin verilmemelidir. ${ }^{26}$

“Toplumsal sorumluluk kuramına göre medyanın amacı, toplumu olup bitenlerden haberdar etmenin, eğlendirmenin ve kar etmenin yanı sıra, temelde, tartışma gündemi için tartışılacak konular bulup çıkarmaktır. Basın, yalnızca yayımcıların uygun gördüğü görüşleri değil, bütün önemli görüşleri aksettirmelidir; böyle yaparken de bütün önemli haber kaynaklarını belirtmelidir. Söyleyecek bir şeyi bulunan herkes, kitle iletişim araçlarından faydalanma hakkına sahip olmalıdır." ${ }^{27}$

Temelinin liberal kuramınkiyle aynı olması nedeniyle gazeteciliğin demokrasiyle ilişkisini sorunsal olmaktan kurtaramasa da toplumsal sorumluluk kuramı, tüm sınırlılıklarına karşın, gazeteciliğin meşruiyet temelini oluşturmasında hala önemini korumaktadir. $^{28}$

Dolayısıyla 1999-2000 yılları arasında nükleer enerji konusundaki egemen söylemin Milliyet gazetesinde nasıl kurulduğuna ve bu üretim sürecinde nükleer karşıtı hareketin temsiliyetine odaklanan çalışma, gazetenin "toplumsal sorumluluğunu yerine getirme" iddiasından ötürü toplumsal sorumluluk kuramını da dikkate alacak, ancak medyayı halkın rızasını sağlamak için egemen değerleri halka aktaran bir araç olarak gören ve eleştirel kuramların dayanaklarından biri olan Hegemonya Kuramına yaslanacaktır.

\section{Yöntem}

Çalışmada, "sosyal ve politik bir tutum" olması nedeniyle bir disiplin olarak tanımlanan eleştirel söylem çözümlemesi ${ }^{29}$ kapsamında, Teun A. van Dijk'in, Mascovici'nin sosyal temsil kuramından hareketle geliştirdiği sosyobilişsel yöntemi referans alınmıştır.

van Dijk’a göre karar verme süreçlerini etkileyen kişiler tarafından ve egemen ideoloji doğrultusunda biçimlendirilen söylem, insanların algılarını yöneterek; hem rıza üretimi sağlamakta hem de onların gelecekteki davranışlarını belirlemekte oldukça etkilidir. van Dijk, söylemin insan davranışları üzerinde bu hakimiyetini nasıl kurulabildiğiyle ilgilenmekte, söylem üzerinden insanların maruz kaldığı manipülasyona dikkat çekmekte ve bunu toplumsal yapıya göre yorumlamaktadır. ${ }^{30}$

Bu doğrultuda van Dijk, disiplin, güç, hâkimiyet, hegemonya, sınıf farkı, cinsiyet, ırk, ideoloji, ayrımcılık, çıkar, dönüştürme, gelenek, sosyal yapı ya da sosyal düzen

26 Vedat Demir, Medya Etiği, İstanbul: Beta Yayınları, 2006, s.33, 37.

27 Vedat Demir, Türkiye'de Medya Siyaset İlişkisi, İstanbul: Beta Yayınları, 2007, s.54.

28 Uzun, İletişim Etiği, s.40.

29 Yasemin İnceoğlu ve Nebahat Çomak, Metin Çözümlemeleri, İstanbul: Ayrıntı Yayınları, 2009, s.30.

30 T.A. van Dijk, “Discourse and manipulation”, Discourse \& Society, 17/3 (2006), s.375, 378. 
gibi konular üzerine çalışmaktadır. Bu konular üzerinden güç ilişkileri, değerler, ideolojiler, kimlik tanımlamaları gibi çeşitli toplumsal olguların, söylem yoluyla bireylere ve toplumsal düzene yansımasiyla ilgilenmektedir. ${ }^{31}$

van Dijk’’n sosyobilişsel yönteminde, "biliş" kavramı büyük önem taşımaktadır. van Dijk, bilişi “düşünce, alg1 ve yeniden sunum gibi zihinsel işlevler dizisi” olarak tanımlamakta; söylem ve toplum arasındaki ilişkilerin bilişsel ögeler üzerinden gerçekleştiğini söylemektedir. ${ }^{32}$

Toplumsal olarak paylaşılan bilgi, inanç-kanaat, tutum ve ideolojiler olarak sıralanabilecek olan sosyal temsiller, bireysel mikro düzey ve toplumsal makro yapilar arasındaki etkileşim ile iletişimin ve toplum ile söylemin ara yüzeyi olan sosyobilişi oluşturur. ${ }^{33}$

Sosyobiliş ise, toplumsal temsiller aracılığıyla oluşturulan ve grup üyeleri tarafından paylaşılan zihinsel stratejiler ve yapılar üzerinden yükselir. Söylem ve toplum üzerindeki bağlar sosyal biliş dolayımlıdır. Bu dolayımı sağlayan araçlar ise zihinsel modellerdir. ${ }^{34}$

"Model" olarak adlandırılan bilginin hafizadaki temsili, metni anlamaya yarayan bir zihinsel yapılandırmadır ve metne ilişkin ayrıntıları da kapsar." ${ }^{35}$ van Dijk’a göre zihinsel modeller, toplumsal olarak paylaşılan bilginin ve muhtemel grup ideolojilerinin iddialarını destekleyen örnekler sağlarlar ve nihai olarak kişisel görüş ve tutumlarımızın biçimlenmesinde rol oynarlar. ${ }^{36}$

Van Dijk, iletişimin bağlamını temsil eden spesifik bir zihni modelinden de söz eder; bağlam modeli, söylemin amaçları ve iletişimsel eylemleri hakkında okuyucunun enformasyonunu belirler. ${ }^{37}$ van Dijk’a göre bağlam modelleri metni, bağlam dolayısıyla toplumla ilişkilendiren temel zihinsel araçlardan biri iken olay modelleri ise söylemi anlamak için gerekli zihinsel işlemin yapılmasını sağlayan çerçeveleri oluşturan temel zihinsel araçtır. ${ }^{38}$

Van Dijk’a göre sosyal biliş dolayımlı ortak bilgi ve inanç-kanaatlerin temel kaynağ 1 medyadır. ${ }^{39}$ van Dijk, haber metinlerini ideolojik birer metin olarak, haberi ise bir

31 T.A. van Dijk, "Handbook of Discourse Analysis", Critical Discourse Analysis, haz., D. Schiffrin, D. Tannen, E.H. Hamilton, Oxford: Blakwell Publishing, 2003, s. 372.

32 T.A. van Dijk, "A Sociocognitive Approach", Methods of Critical Discourse Studies, haz., Ruth Wodak ve Michael Meyer, Londra: Sage, 2015, s.63, 64.

33 T.A. van Dijk, "Social Cognition and Discourse", Handbook of Language and Social Psychology, haz., H. Giles ve W.P. Robinson, New York: Wiley, 1990, s.107.

34 Arcan, İnsan Hakları ve Medya: ABD Elit Medyasında Türkiye’ye İlişkin İnsan Hakları Haberlerinde Söylem İnşası, s.130.

35 Edibe Sözen, Söylem: Belirsizlik, Mübadele, Bilgi/Güçve Refleksivite, Istanbul: Birleşik Yayınları, 2014, s.123. 36, İnsan Hakları ve Medya: ABD Elit Medyasında Türkiye’ye İlişkin İnsan Hakları Haberlerinde Söylem İnşası, s. 130.

37 T. A. van Dijk, “The Interdisciplinary Study of News As Discourse”, Handbook of Qualitative Methods in Mass Communication Research, haz., K. Bruhn-Jensen ve N. Jankowksi, Londra: Routledge, 1991, s.118.

38 Arcan, İnsan Hakları ve Medya: ABD Elit Medyasında Türkiye’ye İlişkin İnsan Hakları Haberlerinde Söylem İnşası, s. 130.

39 van Dijk, “Social Cognition”, s.113. 
tür değil bir söylem olarak görmekte; haber söyleminin toplumda var olan egemen söylemlerin bir ürünü olduğuna, haberlerin gerçeği yansıtmadığını ve gizli ya da açıtan, egemen söylemi tekrar ve tekrar ürettiğini vurgulamaktadır. ${ }^{40}$ Zira söylem yoluyla toplumsal denetim uygulanmasının önemli koşullarından biri de, söylemin denetimi ve bizzat söylemin üretilmesidir: Haber medyasında bilginin bu stratejik denetimi kısıtlı başlık seçimi ve daha genel olarak toplumsal ve siyasal gerçekliklerin özgül yeniden inşaları yoluyla uygulanır. ${ }^{41}$

$\mathrm{Bu}$ nedenle de van Dijk, medyanın nasıl kullanıldığını, toplumdaki etkilerini ve medya kullanıcılarının toplumsal pratikleriyle fikir, tutum veya egemen ideolojilerin nasıl ilişkilendiğini anlamak için bilişsel süreçleri ve ona dahil olan temsiliyetleri detaylı olarak incelemeyi önermektedir. ${ }^{42}$ Ancak bu şekilde açık dilsel yapılardan örtük yapılara ulaşılabilmektedir. ${ }^{43}$

Zira van Dijk’in çözümlemesi, cümlenin yapay sınırlarını reddeder; ${ }^{44}$ bağlam üzerinden anlamlar, fikirler ve ideolojilerin peşine düşer. Başka bir anlatımla haberler metin yapılarıyla sınırlı değildir ve bu yapılar çeşitli alt metinleri, görüşleri ve ideolojileri işaret etmektedir. İşte bu alt metnin, eldeki metinle bağlantısını göstermek için bilişsel, sosyal, politik ve kültürel bağlam analizine ihtiyaç vardır. Bu yöntem, metinde bulunmayanların dil kullanıcıları tarafından anlamlandırıldığı ya da dil kullanıc1larının zihinsel süreçleri tarafından kesin olarak ifade edildiği gerçeğine dayanır. van Dijk buna "söylenmeyenin analizi" demektedir. ${ }^{45}$

Sosyobilişsel yönteme göre eleştirel söylem çözümlemesi yapmanın tek bir yolu yoktur. Ancak çözümlemede mutlaka yapılması gerekenler şöyle sıralanabilir: Söylemin bağlamını incelemek; Hangi grupların, iktidar ilişkilerinin ve ihtilafların bulunduğunu çözümlemek; "Biz" ve "onlar" hakkındaki olumlu olumsuz görüşleri ortaya çıkarmak; varsayılanları ve ima edilenleri ortaya çıkarmak; kutuplaştırılmış grup kanaatlerini vurgulayan tüm biçimsel yapıyı incelemek. ${ }^{46}$

van Dijk’’n eleştirel söylem çözümlemesi makro ve mikro yapı olmak üzere iki ayak üzerinde yükselir. Makroda yapı gazete, kurum, devlet ve toplumsal ilişkilere odaklanılırken; mikro yapıda toplumsallık içinde gazeteci ve haber aktörlerinin ilişkilenme biçimlerine odaklanılır ve zira söylem makro ideolojilerin yansıması olarak mikro düzeyde üretilmektedir. Makro ayak da kendi içinde "tematik" ve "şematik" olmak üzere ikiye ayrılmaktadır. Makro yapı, metnin en önemli bilgisini; özünü anlamsal olarak tanımlamaktadır. Dolayısıyla bu yapının çözümlemesinin tematik kısmında üst başlık, başlık, alt başlık, spot, flaş ve haber metni, fotoğraf ve bunların birbirle-

40 İnal, Haberi Okumak, s.70, 97.

41 van Dijk, "Söylemin yapıları ve iktidarın yapıları", s.319, 326.

42 T. A. van Dijk, “The Mass Media Today: Discourse of Domination or Diversity?” Javnost-The Public; Journal of the European Institute for Communication and Culture, 2 (1995), s.42.

43 İnceoğlu ve Çomak, Metin Çözümlemeleri, s.12.

44 Özlem Güllüoğlu, "Söylen(mey)enin Analizi: Bellona Markasına Yönelik Tüketici Alg1sı Üzerine Bir Söylem Çözümlemesi”, Yazılı Metin Çözümleme, haz., Özlem Güllüoğlu, Ankara: Ütopya Yayınevi, 2012, s. 272.

45 van Dijk, "The Interdisciplinary Study of News As Discourse”, s.114, 117.

46 van Dijk, "Opinions and Ideologies in the Press", Approaches to Media Discourse, haz., Allan Bell ve Peter Garrett, Oxford: Blackwell, 1998, s.61. 
riyle olan bağlantıları hiyerarşik olarak irdelenmektedir. Şematik çözümlemede ise olayın örgüsü, yapı, haberin işleniş biçimi, artalan bilgisi üzerinden yorum yapılır. Mikro yapı çözümlemesi, metni mikro boyutta ele alarak cümleler üzerinde durmaktadır: Cümlelerin basit ya da karmaşık oluşu, etken ya da edilgen oluşu, haberin zamanı, sözcüklerin seçimi, stratejik noktalama işaretlerinin kullanımı, metinde s1fatlar ve alıntılar bu başlık altında incelenmektedir. ${ }^{47}$

Torfing'e göre van Dijk’’n haber metinlerine odaklanan çözümlemesinde esas vurgu şematik yapı ile bunların tematik yapıları nasıl örgütlediği üzerinedir. Zira yazara göre tematik yapı, haber söyleminde metinsel birimlerin hiyerarşik örgütlenmesini ve olası düzenlemelerini belirleyen normlar, kurallar ve kategorilerin bütünü olarak tanımlanan şematik yapı tarafından yapılandırılır. Haber şeması, muhabirlerin ve haber editörlerinin toplumsal ve profesyonel rutinleri tarafından şekillenmekle birlikte, aynı zamanda hem haber üreticilerinin, hem de tüketicilerinin haber söylemini işleme sürecinde onlara bilişsel bir harita sağlamaktadır. ${ }^{48}$

Biliş kavramı üzerinden toplumsallığı ve bağlamı odak noktasına alarak iktidar kavramını denetim aracı olarak gören sosyobilişsel yöntem, nükleer karşıtı hareketin yazılı basının haberlerindeki temsiliyetine odaklanan bu çalışma için eleştirel söylem çözümlemesi disiplinindeki en uygun yöntem olarak değerlendirilmiştir.

\section{Örneklem}

Çalışma, Bülent Ecevit'in başbakanlık koltuğuna oturduğu 11 Ocak 1999 ile Akkuyu nükleer santral ihalesini iptal ederek nükleer enerji konusunu rafa kaldırdığ 25 Temmuz 2000 tarihleri arasına, kendini “Atatürkçü-laik” olarak tanımlayan ve o dönemde Aydın Doğan’a ait olan Milliyet gazetesi üzerinden odaklanacaktır. İhalenin iptalinin ardından 26 Temmuz 2000 tarihli gazetenin 4. sayfasındaki "İptale Milliyet katkısı" başlıklı haberde, gazetenin toplumu uyarma görevinin gerek manşetler, gerekse köşe yazarları üzerinden yerine getirildiği iddiasından dolayı, çalışmaya konuyla ilgili haberlerin yanı sıra, köşe yazılarının ilgili yazıları da dahil edilmiştir.

\section{Dönemin Önemli Nükleer Gelișmeleri}

Çalışmanın odaklandığı 1999-2000 dönemini daha iyi anlamak için, öncelikle 1990'dan itibaren ülkede yaşanan nükleer gelişmeleri değerlendirmek gereklidir. Bu gereklilik,v’ın eleştirel söylem çözümlemesine göre, değerlendirmeye alınan haberlerin artalan incelemesinin yapılması prensibinden de kaynaklanmaktadır. Burada, habere konu olan olayların toplumsal ve siyasi bağlamı yanında, haberin geçtiği zaman ve tarihsel süreçle birlikte değerlendirilmesi de önem kazanmaktadır.

Dönemin başında, 1991'de Arjantin'le nükleer ortaklık için yürütülen görüşmeler, ortak tasarıma Türkiye Elektrik Kurumu ve Türkiye Atom Enerjisi Kurumu ile ilgili yasalarının izin vermemesi yanında, tasarım ve teknoloji üretimi öncesi eğitim

47 T. A. van Dijk, News As Discourse, New Jersey: Lawrance Erlbaum Associates, 1988, s. 30-45.

48 Tezcan Durna ve Çağla Kubilay, "Söylem Kuramları ve Eleştirel Söylem Çözümlemeleri”, Medyadan Söylemler, haz., Tezcan Durna, İstanbul: Libra Kitap, 2010, s.68-69. 
masraflarının çok yüksek çıkması gibi nedenlerle yarım kalmıştır. ${ }^{49}$ Ancak bu sürecin sonu anlamına da gelmemektedir; zira, 1993 başında merkez sağda yer alan Doğruyol Partisi'nin (DYP) genel başkanı ve DYP ve Sosyal Demokrat Halkçı Parti (SHP) koalisyonunun başbakanı Süleyman Demirel'in başkanlığında toplanan Bilim ve Teknoloji Yüksek Kurulu, nükleer enerjiye geçmeyi Türkiye`nin öncelikli 4 meselesinden biri olarak kayda geçirmiş ve 1994 bütçe görüşmelerinde Türkiye’nin nükleer enerjiye geçişi konusunda bütün partiler anlaşmaya vararak, Türkiye Elektrik Kurumu’na Akkuyu Nükleer Santrali'nin ihalesi için izin verilmiştir. ${ }^{50}$

Ocak 1994’te, Türkiye’ye önerilerde bulunacak, teknik şartnameleri hazırlayacak ve teklifleri değerlendirecek bir danışman firma arayışıyla ihale açılmış ve 1995 'te de, danışman olarak Güney Kore`nin KAERI firması ile anlaşılmıştır. Firma, Türkiyeli yetkili kurumlarla birlikte çalışmış, Ekim 1997'de ihale için teklifler alınmıştır. 1998'de tekliflerin değerlendirilmesi görüşmelerin yapılması ve müşavirlik hizmetleri için bir danışmanlık şirketi ile anlaşma imzalanmıştır ${ }^{51}$. Ancak ihale kararının açıklanması çeşitli sebeplerle defalarca kez ertelenecektir.

Öte yandan meslek odaları, sendikalar, siyasi partiler ve çevre örgütleri de birbiri ardına yaşanan bu nükleer gelişmeler üzerine bir araya gelmiştir. Bu bir araya gelişte, 26 Nisan 1986'da SSCB'deki Çernobil Nükleer Santrali’nde yaşanan nükleer kazanın (Türkiye'de o dönemdeki iktidarın ve ilgili bürokratların şeffaf olmayan tutumları, kazanın ardından Çernobil'den gelen radyasyonlu bulutların yol açtığı krizi yönetememeleri nedeniyle) Türkiye'deki olumsuz yansımalarının payının olduğu mutlaka belirtilmelidir. Bununla birlikte, nükleer karşıtı hareketin sesinin yükselmesinde, 1989'da başlayan "Bahar Eylemleri” ve onun tetiklemesiyle 12 Eylül 1980 darbesinin ezdiği toplumsal muhalefetin yükselmesinin de payı vardır.

1980 darbesinin ardından ilk nükleer karşıtı eylem ise, 16 Aralık 1990'da Silifke'de yapılmıştır. 1992 yılında, nükleer karşıtlarının sesi niteliğindeki “Ağaçkakan” dergisi yayın hayatına başlamış ve nükleer karşıtı hareketin teorik altyapısını oluşturan, onu besleyen ve şekillendiren bir misyon üstlenmiştir. Ekim 1995'te ise Uluslararası 1. Nükleer Teknoloji Kongresi'ne alternatif olarak, Nükleer Karşıtı Platformun da kurulması anlamına gelen ilk nükleer karşıtı kongre yapılmış ve bu kapsamda toplanan 17 bin imza, dönemin Meclis başkanı Hüsamettin Cindoruk’a teslim edilmiştir. ${ }^{52}$

İlki 1994’te düzenlenen Akkuyu Nükleer Karşıtı kampı, 2001'e kadar her yıl düzenlenmiştir. Bu döneme nükleer enerjinin ülkeyi geri götüreceği mesajını vermek üzere Mersin'den Akkuyu'ya 170 km’yi geri geri yürümek, bisikletle İzmir'den Akkuyu'ya gitmek gibi bireysel eylemlerin yanı sıra, toplu eylemler de oldukça ses getirmiştir.

Bülent Ecevit’in başbakanlık koltuğuna oturmasının ardından da bu eylemler devam etmiştir. Dönemin Greenpeace Nükleer Enerji Kampanyası Sorumlusu Melda

49 Arif Künar, "Nükleerli Tarihimiz", Don Kişotlar Akkuyu’ya Karşı; Anti-nükleer hikayeler, haz., Arif Künar, Ankara: EMO Yayınları, 2002, s.23.

50 Ahmed Yüksel Özemre, Ah, Şu Atomdan Neler Çektim!, İstanbul: Pınar Yayınları, 2001, s.186.

51 Arif Künar, "Nükleerli Tarihimiz", s.24.

52 Arif Künar, "Nükleerli Tarihimiz", s.41. 
Keskin’in öncülüğünde, Akkuyu Koyu’nun içinde olduğu Büyükeceli Beldesi’nde bir nükleer halkoylaması düzenlenmiş ve halkının yüzde 84’ü Akkuyu’ya nükleer santral kurulmasına "hayır" demiştir. ${ }^{53}$ Sonuçları bir mektupla birlikte Meclise gönderilen bu halk oylaması, Türkiye’nin nükleer karşıtı tarihinde önemli eylemlerden biridir.

Bülent Ecevit, nükleer enerji konusunda zaman zaman çekincelerini ifade etmiş; Nükleer gelişmelere paralel olarak nükleer karşıtı seslerin giderek yükselmesi üzerine "Her iki düşünceyi de dinleyeceğim. Koalisyon ortakları olarak buna göre karar vereceğiz. Şu anda bir görüşüm yok. Ama içgüdüsel olarak endişe duyuyorum" "54 ifadelerini kullanmıştır. Gerçekten de Başbakan Ecevit, Greenpeace Nükleer Enerji Kampanyası sorumlusu Melda Keskin ve yenilenebilir enerji üzerine çalışan ve nükleer karşıtı görüşleriyle bilinen Doç. Dr. Tanay Sıdkı Uyar'la görüşmüş, Uyar’ı kendisine anlattıklarını açıklaması için Aralık 1999'daki Bakanlar Kuruluna davet etmiştir. ${ }^{55}$ Komisyon Liderleri Zirvesi'ne de Akkuyu'da nükleer santral kurmaya karşı çıkan Nükleer Mühendis Prof. Dr. Tolga Yarman da soruları yanıtlamak üzere çağrılmıştır, ancak bu zirvede nükleere "evet” kararı çıkmıştır. Ecevit'in daha sonra nükleer enerjiye karşı çıkan Turizm Bakanı Erkan Mumcu ve Çevre Bakanı Fevzi Aytekin'i ikna etmek için söylediği "Ben de bazı tereddütler taşıyordum ancak yaptığım görüşmelerden sonra tereddüdüm kalmadı”" ${ }^{6}$ sözleri basına yansımıştır. Burada hemen belirtmek gerekmektedir ki, nükleer enerji için ısrar edenlerin başında dönemin Cumhurbaşkanı Süleyman Demirel ${ }^{57}$ ve Ecevit'in koalisyon ortaklarından olan ANAP’lı Enerji Bakanı Cumhur Ersümer ${ }^{58}$ gelmektedir ki bunu Ecevit'in üzerinde kurulmuş bir siyasi baskı olarak da okumak mümkündür. Zira Ecevit, tereddüdünün kalmadığı yolundaki açıklamasından 4 ay sonra, koalisyon ortaklarının itirazlarına rağmen sürpriz bir şekilde 25 Temmuz 2000'de nükleer enerjinin pahalı olduğu gerekçesiyle Akkuyu Nükleer Santrali için açılmış ve yedi kez iptal edilmiş olan ihaleyi son kez iptal etmiş ve nükleer enerji konusunu rafa kaldırmıştır.

Bülent Ecevit'in başbakanlığ 18 Kasım 2002'de sona ermiş ve 2006'da Adalet ve Kalkınma Partisi hükümeti tarafından nükleer enerji konusu raftan indirilerek çalışmalar yeniden başlatılmıştır.

\section{Haberlerin Analizi}

Milliyet gazetesinde bir buçuk yıllık bu dönemde, Akkuyu Nükleer Santral Projesi ile ilgili 50 haber yayımlanmıştır. Çalışmanın bu bölümünde, Milliyet gazetesindeki ilgili haberlerin eleştirel söylem analizi, van Dijk’’n yöntemiyle yapılacaktır. (İncelemeye alınan haberler ve köşe yazılarıyla ilgili ayrıntılı tablolara, buradaki akışı bölmemesi için çalışmanın kaynakça bölümünden sonra ekler bölümünde yer verilmiştir).

53 Melda Keskin, “Akkuyu halk oylaması..., Don Kişotlar Akkuyu’ya Karşl; Anti-nükleer hikayeler, haz., Arif Künar, Ankara: EMO Yayınları, 2002, s.240.

54 Yılmaz, Önder ve Hakan Şanlıtürk, “Nükleer Santrale ‘Evet”, Milliyet Gazetesi, 3 Aralık 1999, s.11.

55 Tanay Sıdkı Uyar, “Enerji Sektöründeki karar vericilerle iletişim ve etkileşimler..., Don Kişotlar Akkuyu’ya Karşı; Anti-nükleer hikayeler, haz., Arif Künar, Ankara: EMO Yayınları, 2002, s. 151.

56 Serpil Çevikcan, Önder Yılmaz, “Turizm ve Çevre Bakanı’nı Ecevit ikna etti”, Milliyet Gazetesi, 2 Mart 2000, s. 16

57 Önder Yılmaz ve Hakan Șentürk, "Nükleer santrale 'evet”, Milliyet Gazetesi, 3 Aralık 1999, s.11.

58 “Hükümette nükleer sorun”, Milliyet Gazetesi, 23 Kasım 1999, s.11. 


\section{Makro Yapı}

Çalışmanın odaklandığı temayla ilgili haberlerin makro yapıları gazete, hükümet(i temsilen Bülent Ecevit) ve devlet olarak karşımıza çıkmaktadır. Toplumsal boyuta odaklanan makro yapı çözümlemesi tematik ve şematik analiz olmak üzere iki bölümden oluşmaktadır.

\section{Tematik Analiz}

Bu bölümde üst başlık, alt başlık, spot/haber girişleri, haber hiyerarşisi ve fotoğraflar incelenecektir.

Başlık: Öncelikle şunu belirtmekte fayda vardır ki; başlıklar kavramsal olarak metni özetler ve metindeki en önemli bilgiyi gösterirler. ${ }^{59}$ Dolayısıyla başlığın kurgulanışı, metnin taşıdığı anlama, metnin hangi gözle yazıldığına ve metnin yönüne dair önemli ipuçları barındırır.

Bu dönemde Milliyet gazetesinde ilk etapta "Hükümette nükleer sorun", "Akkuyu'da karar yok", "Nükleerde fay endişesi", "165 metrede eylem" gibi düz ve haber veren başlıklar dikkat çekmektedir. Zira, gazetenin nükleer karşıtı başlık atmamak için düz başlık kullandığı, böylelikle asıl haberi gizlediği örnekler de mevcuttur. Örneğin, Akkuyu'nun bulunduğu Büyükeceli beldesinde Greenpeace tarafından düzenlenen ve halkın yüzde 84'ünün nükleer santrala hayır dediği halk oylaması haberinin başlı̆ğ, "Nükleer referandum" olarak atılmıştır. Oysa burada haber "nükleer referandum"un yapılmış olması değil yöre insanının yüzde 84’ünün santrale karşı çıkmış olmasıdır. Bu haberde, "Nükleer santrale 'Hayır" şeklinde bir başlık atılmazken, başka bir örnekte Meclis'ten çıkan nükleer enerjiye evet kararı için "Meclis'te nükleer oylama" şeklinde bir başlık değil; "Nükleer santrale "EVET” başlığı tercih edilmiştir. Üstelik "EVET" büyük harflerle ve daha iri puntolarla yazılarak okurun dikkatini çekme amacı güdülmüştür.

Gazetede "Nükleer enerji gerekli" ve "Türkiye nükleerde gecikti" şeklinde haber kaynağının sözünü, olduğu gibi başlığa çıkaran ve sözün kime ait olduğuna başlıkta yer vermeyen, üstelik ifadenin başkasına ait olduğunu göstermek amacıyla ifadeyi tırnak içine almayarak bu görüşe katıldığını da açıktan belirtmiş olan haber örneklerine rastlanmaktadır. Bu tip örneklerde amaç okuru yönlendirmektir. Üst başlıkta sözün sahibinin kim olduğu açıllanmış örnekler de vardır: "MHP Kayseri Milletvekili Gül'den bilim adamlarına: Erken öten horozun kafası kesilir”. Milletvekili Gül, bilim insanlarını basın aracılığıyla alenen tehdit etmektedir ve gazetenin bu sözleri yorumsuz bir biçimde; bunun bir tehdit olduğunu ifade etmeden başlığa çıkarması hem bu tehdidi normalize ederek meşrulaştırmak, hem de yeniden üretmek ve yaygınlaştırmak anlamına gelmektedir.

Gazete bu dönemde nükleer karşıtı üç eyleme yer vermiştir. Üzerinde "Stop Akkuyu" yazılı balonu içindeki iki eylemciyle birlikte uçurarak nükleer enerjiyi protesto eden Greenpeace'in bu eylemi, gazeteye "Baloncu kaçtı kurtuldu eylemciler yakalan-

59 van Dijk, “The Interdisciplinary Study of News As Discourse”, s.113. 
dı" başlığıyla yansımıştır. Başlık "kaçmak", "kurtulmak”, “yakalanmak” kelimeleriyle eylemciler hakkında olumsuz imaj üretmekte, hatta "suçlu" algısı yaratmaktadır.

Gazete, fikri takip olarak adlandırılabilecek şekilde, eylemden sonraki süreci de "Uçanla kaçana ceza yok!" şeklinde haberleştirmiştir. Başlıktan haberin ne olduğu açık değildir; anlaşıldığı kadarıyla balonla havalanan eylemciler hakkında ceza istenmemiş ya da bu eylemcilere ceza verilmemiş, ancak haber metninde balonun havalanmasına yardım eden diğer aktivistler hakkında ceza istenmiş ya da bu aktivistlere ceza verildiği bilgisi vardır. Başlık, hem çevrecileri argo bir ifade ile tanımlayarak itibarsızlaştırırken hem de anayasanın koruma altına aldığı protesto hakkını kullandıkları için diğer aktivistler hakkında neden ceza istendiği ya da bunların neden ceza aldıklarını sorgulamak yerine balondaki aktivistlere neden ceza istenmediğini ya da bunların neden ceza almadıklarını sorgulamaktadır. Üstelik bu bütün aktivistlerin ceza alması gerektiği şeklindeki önyargılı ve yönlendirici alt metin, stratejik noktalama işareti olarak değerlendirilebilecek ünlem işareti ile pekiştirilmektedir.

Gazetede başlıktan manipülasyon yapılan haber örneklerine de rastlanmaktadır. "Nükleer enerjide 2005 beklenmeli" başlıklı haber buna örnek olarak verilebilir. Öncelikle, başlıktaki ifade, kaynak kişi olan Doç. Dr. Baki Akkuş’a ait değildir. Akkuş haberde, "Bize eski teknolojiyi satmak istiyorlar. 2005 yılında çok daha güvenli ve avantajlı santrallar piyasaya sunulacak” demiştir. Ancak asıl haber bu değildir. Asıl haber, Akkuş'a atıfla metinde yer alan "Türkiye’nin kesinlikle nükleer enerji santrallarına ihtiyacı olmadığın, kullanılabilir su kaynaklarının yüzde 30'unu daha devreye sokarak bu sorunun aşılabileceğini belirtti" ifadeleridir ki; bu durumda haberin başlı̆̆ı da Akkuş’a atıfla, "Türkiye'nin nükleer enerjiye ihtiyacı yok" olmalıdır. Bu noktada mutlaka söylenmelidir ki; başlık üzerinden yapılan yönlendirme önemlidir, zira okur gazetedeki bütün haberleri okumasa bile ilgisini çeken haberi bulabilmek için başlıkları okumaktadır. Okurun ilgisini çekmese bile o konuyla ilgili okuduğu başlık artık okurun zihninde yer edecektir.

Gazetede "Halka 'rağmen' teknoloji?”, “Atina: Akkuyu santralına karşı” ve "En pahalı enerji” gibi nükleer karşıtı bir gözle yazılmış haberlerin bazılarının başlıklarında ise "nükleer" sözcügü kullanılmaktan kaçınılmaktadır, böylelikle haberin neyle ilgili olduğunu okur haberi okumadan anlayamamaktadır. Ancak "Doktorlar nükleer enerjiye karşı" ve "Nükleerin zararını bilmiyorum” gibi haber örnekleri de mevcuttur.

Nükleer karşıtı bakış açısıyla verilmiş birkaç haber başlığı da bulunmaktadır. Bunlar arasında "Nükleere karşı tam 80 bin imza" başlı̆̆ ilgi çekicidir. Burada nükleer karşıtı bakış açısını veren sadece "tam” kelimesidir ki; okura 80 bin imzanın çok olduğunu ve pek çok insanın nükleer santral istemediğini ima etmektedir. Kültür sanat sayfasında yer alan "Nükleere hayır şenliğì" başlı̆̆ında ise stratejik noktalama işareti sayılabilecek şekilde "hayır" kelimesi koyu renkle yazılarak ve zemini kırmızı ile boyanarak okurun dikkatini "hayır”a çekmek amaçlanmıştır. Düz başlıkmış gibi görünse de "nükleer" ve "korku” kelimelerinin yan yana kullanılmasıyla birlikte nükleer karşıtı bakış açısının daha belirgin olduğu "Akkuya'da nükleer korku” başlık da buna örnektir. 
Çok fazla kullanılmasa da başlık "165 metrede eylem", alt başlık "Greenpeace grubu nükleer protesto için Boğaziçinin çelik kulelerine tırmandı” örneğinde olduğu gibi üst ve alt başlıklar açıklayıcı, ara başlıklar ise haberin hangi gözle yazıldığına bağlı olarak yönlendiricidir. Üst başlık-başlık ya da başlık-alt başlık uyumundan söz etmek mümkündür ki; bu da başliklar üzerinden okurun zihninde canlanacak bir anlam birliği demektir.

$\mathrm{Bu}$ dönemde atılmış başlıklar arasında en dikkat çekici olanlarından biri de Başbakan Ecevit'in, Akkuyu nükleer ihalesinin karar gününden hemen önce gazetenin Ankara temsilcisi ve köşe yazarı Fikret Bila'ya verdiği tüm bu sürecin sonu anlamına gelen demeç üzerine kurulmuş manşettir. "Nükleer enerji içime sinmedi" şeklindeki manşetin tırnak işareti olmadan atılması dikkat çekmekte, gazetenin de bu fikre katıldığı izlenimi yaratmaktadır. Oysa ki bu, bu süreçte gazetenin başlıklar üzerindeki genel eğiliminin tersi bir durumdur. Manşette her ne kadar “özel haber” logosu varsa da manşete çıkarılan aslında Fikret Bila’nın, Ecevit’in demecini içeren köşe yazısıdır.

Milliyet gazetesinde bu dönemde başlıklarda düz başlık ve egemen söylemi üreten yönlendirici başlık olmak üzere iki belirgin eğilimden söz etmek mümkündür.

Bu dönemde özellikle alt başlıklar dikkat çekicidir. Üst başlıklar açıklayıcı iken başlık düz bir dille yazılmış olsa da alt başlıklar yönlendiricidir. Örneğin "Nükleer anlaşmazlık" başlıklı manşet haberin alt başlı̆̆1 şöyledir: "Enerji Bakanı, 'Türkiyénin mutlaka bir nükleer santrala ihtiyacı var. Koalisyonda mutabakat arıyoruz' dedi” Burada bakanın, nükleer enerjinin bir gereklilik olduğu yoksa Türkiye’nin karanlıkta kalacağ 1 şeklindeki 1970’lerden itibaren kullanılan klasik argümana referansla kullandığ1 ifadeler alt başlığa çıkılmıştır. Başlıkta anlaşmazlığın diğer tarafından söz edilmemekte ve okur yönlendirilmektedir.

Gazetede, alt metin itibariyle nükleer taraftarı gözle alt başlık yazma eğiliminin yüksek olduğu, düz bir başlığa sahip haberlerin alt başlıklarının dahi, nükleer karşıtı söylemi görmezden gelerek nükleer taraftarı söylemi yeniden üretecek şekilde atıldığı söylenmelidir. Bu anlamda çalışmanın ilgilendiği dönem ve gazete üzerinden egemen söylemin alt başlıkta yeniden üretildiği sonucunu çıkarmak mümkündür.

Spot/Haber girişi: Spot ya da haber girişi haberin özetidir ve hem haberin ne olduğunu anlatması hem de haberin sunduğu bakış açısını yansıtması bakımından önem taşımaktadır.

Düz ve haber veren başlıklı haberlerin spotları da genellikle düz ve haber veren spot şeklindedir.

Ancak düz ve haber veren başlıklı haberlerin spotlarının nükleer taraftarı bir gözle, egemen görüşü yansıtacak şekilde yazıldığ leer anlaşmazlık" başlıklı manşet haberin spotu şöyledir: Akkuyu Santralı projesinde sorun yaşadıklarını belirten Cumhur Ersümer, "Nükleer santralın ben çok sağlıklı ve çevre dostu bir enerji kaynağı olduğunu düşünüyorum. Ülkemizin çevresi bunlarla dolu. 10 şiddetinde depreme dayanıkl yapıyorlar” diye konuştu. Hükümet ortaklarıyla 
yllin sonuna kadar bu konuda kesin bir karar verilmesi gerektiğini de vurgulayan Bakan ekliyor: 'Aksi takdirde uluslararası alanda inandırıcılğııızı yitireceğiz. Bundan sonra kimse Türkiye'ye santral teklifi vermez." Burada bakanın herhangi bir bilimsel veriye dayanmadan sadece kendi düşünceleri üzerinden nükleer santralların sağlıklı ve çevre dostu bir enerji kaynağı olduğu yolundaki ifadeleri ve santrallerin dayanıklılığına dair sözleri doğrudan spota çıkarılmış, karşı taraftan söz edilmeyerek okur yönlendirilmiştir. Ayrıca bakanın bir an önce karar verilmesi aksi halde Türkiye’ye kimsenin teklif vermeyeceği yolundaki sözleri ise hükümet üzerinde baskı kurma amaçlıdır.

Hem başlığın hem spotun yönlendirici olduğu örnekler de vardır. "Nükleer santrale 'EVET”" başlıklı haberin spotu şöyledir: "Nükleer santral projesi için liderler zirvesinden olumlu karar çıktı. Demirel 'Bu iş olmazsa, çağın gerisinde kalırız' dedi" Gazete, çıkan kararı "olumlu" olarak değerlendirmekte ve dönemin Cumhurbaşkanı Süleyman Demirel'in sözlerini spota taşımakta, "gereklilik" argümanına atıfta bulunularak okura, zihnindeki "geri kalmış ülke modelleri” işaret edilmektedir.

Hem başlı̆̆ın hem spotun nükleer taraftarı, ancak haber metninin nükleer karşıtı bir gözle yazıldığı örnekler de mevcuttur. Bu örnekler, gazete yönetimi ile muhabirin zihinsel modellerinin zıtlığını göstermektedir. Başlığı "Baloncu kaçtı kurtuldu, eylemciler yakalandı" şeklindeki haberin spotu şöyledir: "Akkuyu'yu protesto için balon uçuruldu. Uçup kurtulan iki çevreci balonu söndürüp evlerine döndü. Gözaltına alınan 9 kişi ise akşam saatlerinde serbest bırakıldı." Spot ve haber başlığındaki cümleler birbiriyle uyumsuzdur ve metinde boşluklar vardır. Üstelik haber metninde aktivistlerin evlerine döndüğ̈ gibi bir bilgiye rastlanmazken bu bilgi, sadece balondakilerin ayrıcalıklı olduğu, o yüzden gözaltına alınmadıkları imasında bulunmak için spota yerleştirilmiştir. (Bu haber örneği, Mikro Yapı başlığı altında ayrıca değerlendirilecektir.)

Hem başlığı hem de spotu nükleer karşıtı bir gözle yazılmış örneklere de rastlanmaktadır: "Akkuyu'da yapılması düşünülen nükleer santralın riskli fay hatlarının çok yakınında bulunması yüzünden olası bir depremde tüm Akdeniz havzasının bundan etkileneceği, sakat birakacak hatta öldürecek radyasyon bulutlarmın çevreye yayılacağı belirtildi."

Bu noktada belirtmek gerekmektedir ki; gazetedeki başlık, alt başlık ve spotun, haber metni ile uyumlu olmadığı örnekler, gazetede yazı işleri gibi düşünmeyen muhabirlerin bulunduğu anlamına gelmektedir. Ancak gazete bu uyumu yakalamak için uğraşmak ve haber metinlerinin de kendi istediği gibi kurgulanmasını sağlamak yerine yönlendirmeyi başlık ve spot üzerinden yapmaktadır.

Gazetede, alt metin itibariyle nükleer taraftarı gözle spot/haber girişi yazma eğiliminin yüksek olduğu, düz bir başlığa sahip haberlerin spotlarının dahi, nükleer karşıtı söylemi görmezden gelerek nükleer taraftarı söylemi yeniden üretecek şekilde atıldığ̣ söylenmelidir. $\mathrm{Bu}$ anlamda çalışmanın ilgilendiği dönem ve gazete üzerinden egemen söylemin (alt başlık ve) spotta yeniden üretildiği sonucunu çıkarmak mümkündür. 
Fotoğraflar: Fotoğraflar genellikle haberi kanıtlamaya yöneliktir. Nükleer karşıtı eylem fotoğraflarında nükleer karşıtı dövizler ve pankartlardaki yazıların okunabilir olmasına dikkat edildiği görülmektedir. Ancak eyleme polis müdahalesi olmuşsa mutlaka müdahale ya da gözaltı sırasında çekilmiş fotoğraflar da kullanılmaktadır. $\mathrm{Bu}$ fotoğraflar bir yandan "gözaltına alındılar" bilgisi kanıtlanırken öte yandan da çevreciler hakkında olumsuz imaj üretmekte ve suçlu algısı yaratmaktadır.

Ekonomi ve politika sayfalarındaki nükleer haberlerin fotoğrafları ise, genellikle haberi tamamlamaya yönelmiştir; zaman zaman temsili bir nükleer santral fotoğrafı ya da nükleerle ilgili demeç veren siyasetçinin portresi kullanılmıştır.

Haber hiyerarşisi: Bu dönemde Akkuyu Nükleer Santralı öznelinde Akkuyu nükleer santrali ile ilgili gazetede çıan 50 haberin üçü gazeteye manşet olmuştur. Bunların yanı sıra Fikret Bila’nın Bülent Ecevit ile görüşmesini aktardı̆̆ı bir köşe yazısı da gazetede manşetten görülmüştür. Dört haber ikinci manşet ve bir haber de sürmanşet olarak birinci sayfadan okurlara duyurulmuş, üç haber de birinci sayfada kisa olarak yer almıştır. İçeride ise ilgili haberlere genellikle güncel, ekonomi, politika, çevre ve dış haberler sayfalarında yer verilmiştir. İç sayfalarda bu haberlerin 16’sı sayfa manşeti, 13 'ü ise ikinci manşet olarak değerlendirilmiştir.

Dikkat çekmektedir ki; konuyla ilgili haber paketlerinin içinde yer alan haberlerin hiyerarşisinin kurgulanışı da ideolojiktir. Örneğin gazetenin birinci sayfadan "Ankara: Enerji açı̆̆ı var, santral şart... İstanbul: Yalan” üst başlı̆̆ı ve "Nükleer çatışma çıktı” başlığıyla sürmanşet olarak gördüğü haber paketinde, Türkiye Atom Enerjisi Kurumu'nun (TAEK) başbakan Bülent Ecevit'e sunduğu ve Türkiye'nin enerji açı̆̆1nın ancak nükleer santrallerle kapatılabileceği yolundaki raporun haberi soldan sağa okuma sırasına göre önce verilmiştir. Elektrik Mühendisleri Odası'nın (EMO) bu raporu yalanladığı haber ise sağda bulunmaktadır. İç sayfada ise TAEK haberi sayfa manşeti, EMO'nun açıklamaları ikinci manşettir. Gazetede okurun aklında asıl kalması istenen haber önce sunulmaktadır. Bu haber örneğinde, okura önce açıklamayı daha sonra bu açıklamaya yapılan itirazı sunmanın mantık dahilinde olduğu, dolayısıyla bunu ideolojik kurguyla açıklamanın abartılı olacağı iddia edilebilir. Ancak bu iddiayı şu örnek çürütmektedir:

Milliyet muhabiri Nazım Alpman'ın Akkuyu halkıyla konuşarak hazırladığı "Köylü Ankara'ya 'Ayaklanacağız, haberiniz olsun' mesajı yolluyor" üst başlıklı "Akkuyu Karakuyu belli olacak!' başlıklı geniş haberi iç sayfa manşetidir. Konuyla ilgili olduğu için bu sayfada "Toprăga bakmak lazım" başlığıyla verilen Kaliforniya Teknik Üniversitesi öğretim üyesi Prof. Dr. Jean-Pierre Bardet'in deprem saikiyle Akkuyu'da nükleer santral yapılmaması gerektiği şeklindeki ifadelerini içeren haber ve yukarıda da anıldı ğı üzere deprem saikiyle Akkuyu'ya karşı çıkan bilim insanlarına MHP Kayseri Milletvekili Gül'ün "Erken öten horozun kafası kesilir” şeklindeki tehdidini içeren diğer bir haber de yer almaktadır. Bir önceki örnekte olduğu üzere, önce bilim insanlarının açıklamasını ve sonra bu açıklamaya gösterilen tepkiyi vermek akla yatkınken, Milliyet gazetesi üst tarafta vekilin tepkisini içeren haberi bunun altında ise bilim insanlarının açıklamalarını içeren haberi okurlarına sunmuştur ki, buradan da hi- 
yerarşik kurgunun ideolojik saiklerle yapıldığı anlaşılmaktadır. Vekilin tehdit içeren açıklamalarını okuduktan sonra okur, gözünde "itibarsızlaşan” bilim insanlarının açıllamalarını okusa bile, bu açıklamaları güvenilmez bulacak ve önemsemeyecektir.

Meclisteki toplantıların haberlerinde nükleere karşı çıkanların da nükleer enerjiyi savunanların da ifadeleri yer almaktadır. Ancak nükleer enerjiyi savunan siyasetçilerin verdiği demeçler karşıt görüşe ihtiyaç duyulmaksızın haberleştirilirken, nükleer enerjiye karşı tereddütle yaklaşan bir siyasetçinin demeci, nükleer taraftarı başka bir görüş daha alınarak haberleștirilmektedir.

Belirtmek gerekmektedir ki, kaynağı nükleer karşıtı hareket olan haberler, diğerlerine göre haber hiyerarşisinde daha alt sıralarda yer almaktadır.

\section{Şematik Analiz}

Bu başlık altında nükleer ile ilgili haberler “durum” ve “yorum’ üzerinden incelenecektir. Durum kısmında olayların ele alınış ve işleniş biçimine, bağlam ve artalan bilgisi üzerinden olayların toplumsal ve politik yönlerine, olaylar hakkındaki bilgilerin tam olup olmadığına; hangi bilginin maskelendiğine ve hangi bilgiye haberde yer verilmediğine odaklanılacaktır. Yorum kısmında ise haber kaynakları ve tarafların olaya bakış açısı ortaya konacaktır.

Durum: Milliyet gazetesinin bu dönemde okurlarına Akkuyu ile ilgili haberleri; nükleer ihalede yaşanan gelişmeler, hükümetin bu konudaki açıklamaları, diğer devletlerin tutumu, nükleer karşıtlarının eylemleri ve açıklamaları ve yöre insanının bu konudaki düşüncelerinden oluşmaktadır.

Gazete nükleer enerji konusuna hem ekonomik hem de politik bir konu olarak yaklaşmaktadır. Ekonomi sayfalarındaki ilgili haberler genellikle ihalenin teknik detaylarına odaklanırken politika sayfalarındaki haberler sistematik olarak "ihtiyaç/gereklilik” bağlamında kurgulanmakta ve Türkiye’de hükümetlerin 1970’lerin başındaki petrol krizinin ardından nükleer enerjiye yönelen dünyaya yetişme çabasının da bir ifadesi olan, "Enerji açığımız var, nükleer enerjiye geçmezsek karanlıkta kalırız", "Nükleer enerjiye geçmezsek çağ dışı kalırız" ve "Güçlü bir ülke olmak için nükleer enerji gerekli” şeklindeki argümanları yeniden üretmektedir. Bu noktada hemen belirtmekte fayda vardır ki; gazetede hükümet başkanı Bülent Ecevit’in gölgelendiği örneklerin sayısı da az değildir. Gazete, Ecevit’in çekinceli sözlerinin üzerine kurulu haberlerde dahi, nükleer enerjiyi savunan başka siyasetçilerin ifadelerini başlığa ve spota çıkararak Ecevit'i gölgelemiş ve okuru yönlendirmiştir.

Özellikle bu sayfalardaki haberlerde gazete aktarıcı konumdaymış gibi görünse de haberler yönlendiricidir. Hükümet mensuplarının ya da siyasetçilerin yukarıda örneklenen ifadelerin bulunduğu -nükleer enerji taraftarı- demeçleri gazete tarafından aktarılmakta ve ancak bu görüşe karşı çıkan, örneğin meslek odaları temsilcilerine ya da nükleer karşıtı harekete yer verilmemektedir. Üstelik yöre insanı başta olmak üzere, ülkede nükleer santrale karşı çıkan bir kesimin olduğu bilgisi yer almadığından haberde kayıp halkalar oluşmaktadır ki, bu da ideolojik bir seçim olarak dikkat 
çekmektedir. Bu noktada okurun rızasının sağlanması için ekonomi ve politika sayfalarının en uygun zeminler olduğu belirtilmelidir.

Gazetenin nükleer karşıtlarına yaklaşımını da mesafelidir. Gazetenin bu dönemde hayli aktif olan Nükleer Karşıtı Platformu, onun açıklamalarını ve eylemlerini sistematik olarak görmezden gelmektedir. Ancak gazete, Nükleer Karşıtı Platformun üyesi olan Greenpeace'in eylemlerine ve açıklamalarına yer vermektedir. Zira Greenpeace, dünya çapında popüler bir çevre örgütüdür ve haber değeri yüksek eylemler ve açıklamalar yapmaktadır. Ancak Greenpeace'in yabancı kökenli bir çevre örgütü olması, yabancı aktivistlerin gelerek Türkiyede eylem yapması ve hatta adının İngilizce olması, "yabancılar” adı altında üretilen "belirsiz düşmanın” Türkiye’nin kalkınmasını istemediği yolundaki argümanının bu şekilde "modellendirilmesi" okurun zihin dünyasında, Greenpeace’in söylemlerinin tam tersi bir etki yaratmaktadir.

Gazetede bu dönemde muhabirin bölgeye giderek yöre halkının görüşlerini aktard1ğ1 iki haber mevcuttur. Ancak bu haberlerde yöre halkına dair "isyancı” imajı üretilmekte ve nükleer enerjiye karşı çıkan bu insanların yanı sıra nükleer enerjiyi savunan köylülerin olduğu da vurgulanmaktadır.

1986 Çernobil nükleer kazasının etkileri halen akıllardayken bu dönemde Milliyet gazetesinde Akkuyu nükleer santrali ile ilgili haberlerde, kaynak olarak çevrecilerin bir kaç açıklamasını konu alanlar hariç, Çernobil'den söz edilmemiş, nükleer kaza olasılığına değinilmemiş, bu konu görmezden gelmiştir.

Yorum: Bu dönemde Akkuyu Nükleer Santrali öznelinde nükleer enerji ile ilgili gazetede çıkan 50 haberin sadece 11 tanesinde haber kaynağı nükleer karşıtı harekettir. Bunlardan ikisi yazılı basın açıklaması, ikisi eylem ve ikisi de bu eylem sonucunda açılan davalar ve aktivistlerin sınır dışı edilmesinin haberi olmak üzere 6'sı Greenpeace ile ilgilidir. Biri İstanbul Tabip Odasının nükleer karşıtı açıklamasıdır. 2 haber Akkuyu köylülerinin görüşlerini aktarmaktadır ki bunun için gazetenin yöreye muhabir gönderdiğini not etmek gerekmektedir. 2 haberde kaynak kişi bilim insanlarıdır. Bunun dışındaki haberlerin kaynakları siyasetçiler ve bürokratlardır. Dolayısıyla, gazetenin seçmeci ve tek düze kaynak anlayışıyla egemen söylemi yeniden ürettiği söylenebilir.

Türkiye'de 1970'lerin başında nükleer enerjiye karar verildiğinden itibaren bir devlet politikası olarak bütün hükümetler nükleer enerjiyi savunmuştur. Buna, o dönemde Demokratik Sol Parti'nin koalisyon ortakları Anavatan Partisi ve Milliyetçi Hareket Partisi de dahildir. Başbakanlık koltuğunda oturan Bülent Ecevit ve partisi Demokratik Sol Parti ise bu konuda çekincelidir. Bilim insanlarının bir kısmı nükleer enerjiyi savunurken bir kısmı da karşı çıkmaktadır. Akkuyu Nükleer Santrali’ne karşı çıkanlar arasında, Avrupa Birliği ile nükleer karşıtı hareketin içindeki meslek odaları ve çevre örgütleri de bulunmaktadır.

Gazetede nükleer taraftarı argümanlar görünür durumdadır ve bunlardan en sık tekrarlananı "Nükleer enerjiye ihtiyacımız var" şeklindedir. Bu argüman, zaman za- 
man "yoksa karanlıkta kalırız", zaman zaman da "yoksa güçlü bir ülke olamayız" ifadesi ile tamamlanmaktadır.

Gazetede nükleer karşıtı argümanların, nükleer taraftarı argümanlara kıyasla çok daha az görünür olduğu söylenmelidir. Nükleer karşıtı argümanlar arasında gazetede kendine en çok yer bulan argüman ise "Akkuyu'dan Ecemiş fay hattının geçtiği ve olası bir depremde nükleer santralin güvenliğinin söz konusu olamayacağı” şeklindedir. Bu argümanın bu dönemde öne çıkmasının nedeni, 1998 yılında Adana'da 1999'da ise Marmara Bölgesi'nde ve Düzce'de çok şiddetli depremlerin yaşanmış olmasıdır. Bunun haricinde "Nükleer enerji pahalıdır. Onun yerine yenilenebilir enerji kaynaklarına geçilmelidir” argümanı ve nükleer atık sorununun çözümsüzlüğü ve nükleer enerjinin halk sağlığını tehdit ettiği konusu gazetede rastlanan nükleer karşıtı argümanlardandır.

\section{Mikro Yapı}

Çalışmanın odaklandığı dönemde, ilgili haberlerdeki mikro yapılar nükleer karşıtları ve gazetecilerdir. Bu başlık altında gazetecilerin olayın aktörleriyle kurduğu ilişkilere odaklanılacaktır. Bu başlık altında birbirini takip eden cümle ve cümleciklerin birbirleriyle uyumuna dikkat edilerek sentaktik çözümleme yapılacak, sözcük seçimi ve stratejik noktalama işaretlerinin kullanımı da dahil olmak üzere haberin biçemi ve retoriği incelenecektir.

Sentaktik çözümleme: Cümleler genellikle uzun ve birbirleriyle uyumludur. Ancak cümleler arasındaki uyumun kaybolduğu örnekler de mevcuttur. Aradaki uyumun kaybolması devreye okurun zihinsel modelinin girmesi anlamına gelmektedir. Hangi gözle yazıldığından bağımsız olarak genellikle pasif yapının kullanımı dikkat çekmektedir. Örneğin aktivistlerin polis tarafından gözaltına alındığı, ya da açıklamanın bilim insanları tarafından yapıldığı yazılmamaktadır. Böylece pasif yapı "kim" sorusunun yanıtını yok ederek haberin anlamıyla oynamakta, vurguyu kaydırarak okurun dikkati başka noktalara çekmektedir.

Sözcük seçimleri ve noktalama işaretleri: Mikro düzeyde üretilen söylemler arasındaki farkı görmek için Milliyet gazetesinde aynı konuda yazan iki farklı muhabirin haberlerine bakmak yerinde olacaktır. Başlıklar ve spotlar makro yapılara işaret ettiğinden burada sadece haber metinlerine yer verilecektir:

Tarih: 11 Nisan 1999

Muhabir: Aslı Ökten

“Greenpeace çevre örgütü üyeleri, Akkuyu'da kurulması planlanan nükleer santralı protesto için dün bir balon uçurma eylemi gerçekleştirdi.

Eylemden önce, Greenpeace Akdeniz Ofisi Enerji kampanyası Sorumlusu Melda Keskin bir açıklama yaptı. Nükleer enerjinin ekolojik olarak sürdürülemez ve pahalı olduğu konusunda hükümeti uyardıklarını söyleyen Keskin, "Aktif faylı bir bölgede kurulması düşünülen Akkuyu Nükleer Santral,, Türk cumhuriyet- 
lerinden Ortadoğu'ya kadar radyoaktif felakete neden olabilir" dedi. Daha sonra, "Stop Akkuyu (Akkuyu’yu durdurun)" yazılı balonu uçurup nükleer ölümü temsilen yere yatan Keskin ve 8 Greenpeace üyesi göz altına alındı. İki üyeyle uçurulan Greenpeace balonu ise, daha sonra İstanbul Ticaret odast yanındaki alana indi. Göz altındaki çevreciler, öğleden sonra serbest bırakıldı."

Tarih: 16 Nisan 1999

Muhabir: Nezih Gürol

"Akkuyu'ya kurulması planlanan nükleer santrah protesto etmek için Sultanahmet Meydaninda eylem yapan Greenpeace üyelerinden göz altına alınan 9 Türk hakkında "izinsiz gösteri" yaptıkları gerekçesiyle üç yıla kadar hapis cezası istemiyle dava açıldı. Eylem sırasında "Stop Akkuyu" yazıll balonda gökyüzüne havalanan Fransiz ve Avusturyalı iki uyamı eylemci ise yargılanmaktan kurtuldu."

İlk haberde Greenpeace "çevre örgütü", Greenpeace üyeleri ise "çevreci” olarak tanımlanmıştır. Buradan haberi yazan muhabir Aslı Öktem'in Greenpeace'i bir terör örgütü ya da ajanlık yapmak amacı güden bir yapı; Greenpeace üyelerini ise terörist ya da ajan olarak görmediği sonucuna varılabilir. Muhabir haberde aktivistlerin görüşlerine gerek dolaylı, gerekse doğrudan alıntılarla yer verilmiştir. Dolaylı alıntılarda "iddia etti", "öne sürdü" gibi stratejik eylemler yerine "söyledi", "dedi" gibi daha düz eylemleri tercih etmesi en azından açılamanın savunduğu fikre karşı çıkmadığını göstermektedir. Eylemcilerin protesto amacıyla yere yatmasını, "nükleer ölümü temsilen" şeklinde değerlendiren muhabir, nükleer enerji ile ölüm arasında ilişki kurmaktadır. Bu haber metninde çevreciler kriminalize edilmemiş, gözaltına alınan çevrecilerin daha sonra serbest bırakıldığı bilgisi de haberin sonuna eklenmiştir.

$\mathrm{Bu}$ haberin devamı niteliğindeki, başka bir muhabir; Nezih Gürol tarafından yazılan haberin bakış açısı ise tamamen tezattır. Öncelikle Greenpeace'in haberde tanımlanmamış olması, muhabirin Greenpeace’e karşı mesafesinin ve ideolojik tutumunun bir göstergesidir. Öte yandan Greenpeace'in tanımlanmamasıyla okura birakılan bu ve bunun gibi boşluklar, haberde geçen "gözaltı", "dava" ve "izinsiz gösteri” kavramları hakkındaki sosyal ve ortak bilgi aracilığıyla okurun zihnindeki model ile tamamlamakta ve okurun zihninde suçlu algısı yaratılmaktadır. Haberdeki ayrımcılık da dikkatlerden kaçmamaktadır. Haber "9 Türk" hakkında dava açıldığından ve fakat balonla havalanan yabancılara dava açılmadığından söz etmektedir. Oysa hakkında dava açılan aktivistlerin Türk oluşunun belirtilmesi bağlantısızlığa bir örnektir ve sanki Türk oldukları için dava açılmış gibi ideolojik bir ima içermekte ve okurun zihnindeki milliyetçi duygulara hitap etmektedir. Hakkında dava açılmayan iki yabancı uyruklu eylemci ise, haberde "uyanık" olarak tanımlanmış ve eylemcilerin balonla, polisten kaçmak için havalandıkları ima edilmiştir. Haberde haklarında dava açllan Greenpeace üyelerine mikrofon uzatılmamış, haber okura tek taraflı olarak aktarılmıştır.

Nükleer karşıtı hareketi kaynak olarak alan bazı haberlerde genellikle stratejik ey- 
lemlerin kullanıldığına rastlanmaktadır ki bu, haberin karşıt bir gözle yazıldığı anlamına gelmektedir. Zira stratejik eylem kullanımı, dil açısından belirleyici unsurlardan biridir.

Gazetede dil kullanımı açısından diğer bir belirleyici unsur olan ünlem işareti, tırnak işareti ve metnin önemli kısımlarını daha kalın karakterle ya da koyu yazmak, büyük harf ya da farklı renk kullanmak gibi stratejik noktalama işaretlerine de sıklıkla başvurulmaktadır. Stratejik noktalama işaretleri zaman zaman okurun dikkatini çekmek için zaman zaman da yazılana ters bir anlam katmak, bu anlamı ima etmek için kullanılmaktadır.

\section{Biçem ve retorik}

"Biçem, farklı kelimeler ya da söz dizimsel yapılar kullanılarak, aynı şeyin az ya da çok korunduğu çeşitli alternatif yollar arasında yapılan seçimin metinsel bir sonucudur. Bu tür biçemsel seçimlerin aynı zamanda açı olarak sosyal ve ideolojik imaları vardır, çünkü bunlar çoğunlukla muhabirin, haberin aktörleri ve habere konu olan olay hakkındaki düşüncelerine, sosyal ve iletişimsel durumun özelliklerine ve söz konusu muhabirin beyaz, erkek ve orta sınıftan olması gibi muhabirin grup aidiyetine işaret ederler." ${ }^{\prime 60}$

Sözcük seçimi, stratejik eylem ve noktalama işareti kullanımında da anlaşılabileceği üzere Milliyet gazetesinde bu dönemde hem nükleer karşıtı hem de nükleer taraftarı dile rastlanmaktadır. Haberlerin çoğunda dil, yönlendirici bir biçimde kullanılmaktadır.

Nükleer karşıtı hareketi kaynak olarak alan haberlerin bir kısmı nükleer karşıtı bir dille yazılmıştır. Nükleer taraftarı bir dille yazılmış olanları ise bunu genellikle stratejik eylemlerle sağlamışlardır ki, stratejik eylem kullanımı, dil açısından belirleyici unsurlardan biridir.

Politika sayfalarından siyasetçileri kaynak alan haberlerde ise -başlık ve spottan bağımsız olarak- dengeli bir dil göze çarpmaktadır. Ancak bu haberler genellikle siyasetçilerin görüşlerini ve kullandıkları argümanları doğrudan alıntı ile aktarmakta ve "Enerji açığımız var, nükleer enerjiye geçmezsek karanlıkta kalırız", "Nükleer enerjiye geçmezsek çağ dışı kalırız" ve "Güçlü bir ülke olmak için nükleer enerji gerekli" şeklindeki argümanları yeniden üretmektedir. Bu argümanlardaki karanlık, güçsüzlük, çağdışılık okurun zihinsel modellerinde gaz lambası, karneyle ekmek almak, savaş gibi zor zamanların temsiline denk düşmekte ve böylelikle okura, o zor günlere dönmemenin koşulunun nükleer enerji olduğu ima edilmektedir.

Özellikle başlık, spot ya da haber girişlerinde "bilim adamları karşı çıkıyor", "çevreciler kızgın” gibi genellemelere rastlanmaktadır ki bunlar okuru, haberin özünden ve öznesinden uzaklaştırmaktadır.

60 van Dijk, “The Interdisciplinary Study of News As Discourse”, s. 115, 116. 
Haberlerde inandırıcılığı arttırmak için görgü tanıklarının ifadelerine, bilim insanlarının değerlendirmelerine ve rakamlara yer verilmekte, ancak bunlar haberin bakış açısına ya da diline göre yönlendirmeli olarak okura sunulmaktadır.

\section{Köşe Yazılarının Analizi}

Öncelikle mutlaka belirtmek gerekmektedir ki Türkiye’de köşe yazıları, gazetenin yayın çizgisini doğrudan yansıtmak durumunda olmayıp yazarın görüşlerini açıkça yazabildiği mecralardır. Dolayısıyla haberlerde rastlanan örtük anlamlara köşe yazılarında rastlanmaması şaşırtıcı olmayacaktır.

Gazetede bu dönemde Akkuyu nükleer santrali ile ilgili 33 köşe yazısı yayımlanmıştır. Gazetenin Ankara temsilcisi Fikret Bila konuyla ilgili sık sık yazan isimlerdendir. Bila’nın yazılarının başlıkları genellikle "Büyük Pazarlık" ve "Nükleerde ABD Atağı", "Nükleere Fren” örneklerinden de görüldüğü üzere düz, haber veren başlıkladır. Bila, bulunduğu konum itibariyle de dönemin başbakanı Bülent Ecevit’e yakın isimlerden biridir, dolayısıyla kendi görüşlerinden çok Ecevit'in değerlendirmelerini ve görüşlerini okura aktarmaktadır. Ecevit'in nükleer enerji konusunda kararlı olduğu zamanlarda yazıları nükleer yanlısı bir söylem, şüphe duyduğu zamanlarda ise nükleer karşıtı bir söylem içermektedir. Bu anlamda Bila’nın yazılarında Ecevit'in nükleer enerji ile ilgili fikirlerindeki değişim de izlenebilmektedir. Örneğin, Fikret Bila 14 Ekim 1999'da “Nükleer enerji konusunda tereddüdünüz var mı?” sorusuna, Ecevit'in "Benimki nükleer enerjiye karşı çıkmaktan çok 'acaba füzyon teknolojisini bekleyemez miyiz' düşüncesi” şeklinde yanıt verdiğini aktarırken, 24 Temmuz 2000'de gazetenin manşete taşıdığı yazısında, Ecevit'in endişeli olduğunu ve nükleer enerjiye geçiş kararını içine sindiremediğini yazmıştır. Bila yazılarında, nükleer karşıtı hareketten söz etmemiş, nükleer karşıtlarına referans vermemiştir, ancak Ecevit'in nükleer karşıtlarıyla da görüştügünü aktarmıştır. Stratejik noktalama işareti olarak yazılarında sık sık kendince önemli kısımları koyu renkte yazmış olan Bila, anlaşılabilir bir dil kullanmiştır.

Konuyla ilgilenen ekonomi yazarı Meral Tamer ise genellikle "Nükleersiz Bayramlar", "Dünya Nükleerden Dört Nala Kaçıyor" ve "Nükleer: İptal Etmek İtibarımızı Arttırır” örneklerinde olduğu gibi, nükleer karşıtı bakış açısını yansıtacak şekilde başlıklar tercih etmiştir. Tamer, nükleer enerjiye ve Akkuyu nükleer santralinin kurulmasına açıktan karşı çıkmıştır ve nükleer enerjiden vaz geçilmesi için hükümete çağrı yapmıştır. Bunun için zaman zaman uzun yazılar yazmaktan ve değerlendirmeler yapmaktan da, teker teker nükleer taraftarı argümanlara yanıt vermekten de çekinmemiştir. Yazılarında, ekonomik ve istatistiksel veriler kullanarak nükleer enerjinin pahalı olduğunu ve dünyada terk edilmekte olan bir enerji çeşidi olduğunun üzerinde durmuştur. Tamer' in yazılarında nükleer karşıtı hareket olmasa bile, nükleer karşıtı argümanlar son derece açıktır; hatta, Tamer’in nükleer karşıtları için yeni argüman sağladığı da söylenebilir. Tamer, ihalenin defalarca kez ertelenmesinin olumlu olarak karşılamış, bu konuda hükümeti kutlamaktan geri durmamış ve hükümete ihaleyi ertelemek yerine tümden iptal etmeyi de tavsiye etmiştir. Tamer, 22 Temmuz 2000 tarihli "Nükleer: Íptal etmek itibarımızı arttırır" başlıklı yazısında, 
dönemin Enerji Bakanı ANAP'lı Cumhur Ersümer tarafından kendisine 5 milyar liralık tazminat davası açıldığını yazmıştır. Tamer de, Bila gibi stratejik noktalama işareti olarak sık sık yazılarının kendince önemli kısımlarını koyu renkte yazmaktadır.

Konuyla zaman zaman ilgilenen diğer isim olarak Melih Aşık dikkat çekmektedir ki; Aşık da "Nükleer Tezgah...", "Malum Ucuz Hikaye" gibi yorumlu başlıkları tercih etmiş ve nükleerin bir aldatmacadan ibaret olduğunu ima etmiştir. Meral Tamer'in aksine Aşık, yazılarında nükleer karşıtlarına argüman üretmemiş, ancak nükleer karşııı harekete ve onun argümanlarına yer vermiş, bu argümanların yeniden üretilmesini ve yaygınlaşmasını sağlamıştır. Aşık, Akkuyu Nükleer Enerji Santrali’ne gerek olmadığını, bunun yerine yenilenebilir enerjinin yeterli olacağını, bu alandaki etkin isimlere dayanarak savunmuştur. Aşık da stratejik noktalama işareti olarak sık sık yazılarının kendince önemli kısımlarını koyu renkte yazmıştır.

Üç hafta birbiri ardına bu konuyu yazan, fakat daha sonra gazeteyle yollarını ayıran Fikri Sağlar ise, "Akıllı Olmak!", "Dost Uyarıyor" ve "İhale ve İhanet!” başlıklarını tercih etmiş; nükleer ihaleyi vatana ihanetle eş tutmuştur. Kendisi de Mersin'li olan Sağlar, iki yazısında Yunanistan tarafından hazırlanan bir fay hattı raporundan söz etmiş ve raporda gösterilen Akkuyu yakınlarındaki fay hattı nedeniyle Akkuyu Nükleer Santrali’nin riskli olduğu yolundaki tespitlerini aktarmıştır. Sağlar, açıktan rapordaki uyarıyı tekrarlamış ve “Akkuyu nükleer santralini yapmayın” demiştir. Özellikle deprem riskini öne çıarsa da Sağlar, yenilenebilir enerji kaynakları ve nükleer atıkların doğadan yok edilememesinin üzerinde de durmuştur.

Gazetede, açıktan nükleer enerjiyi savunan bir köşe yazısı yayımlanmıştır ki, bu da konuyla ilgili zaten sadece bir yazı kaleme alan Doğan Heper'in "Elektrik kesintisi ayıbı..." başlıklı yazısıdır. Heper yazısında, "Nükleer santrallar olmazsa çağın gerisinde kalırız" diyen dönemin Cumhurbaşkanı Süleyman Demirele referans vermekte, görüşlerine bu konuda Türkiye Atom Enerjisi Kurumu Başkanı Prof. Dr. Cengiz Yalçın’ın "Türkiye'nin nükleer enerjiye ihtiyacı var" minvalindeki sözlerine ve 16 ülkenin nükleer enerji tüketimini arttırdığını söyleyen BP-Amoco’nun 1999 Dünya Enerji Raporuna dayandırmaktadır. Heper'in yazısında nükleer enerjiye karşı çıkanların varlığından da söz edilmiş̧tir.

Hasan Cemal, "Kafam karışık, nükleer enerji konusunda..." başlıklı yazısında, iki tarafın argümanlarını sıralayıp her iki tarafın da kendisini ikna etmediğini söyleyerek, köşesinde reklamcı ve yayıncı Nazar Büyüm'ün "Nükleer enerjiye sorgusuz sualsiz karşı çıkmak elbette akıl işi değil. Halkını tartışıp ikna etmeden bütün ülkeyi nükleer santrala mahkûm etmek akıl işi mi?" diye soran mektubuna yer vermiştir. Mektupta, öz itibariyle bu konunun neden tartışılmadığını sorgulamakta ve bir anlamda yurttaşların katılım hakkına ve kamu için tartışma platformu yaratılmasına vurgu yapmaktadır. Bu yönüyle önemli bir mektup ve önemli bir yazıdır.

Gazetede bu dönemde yayımlanan köşe yazılarının dışında, biri Akkuyu Nükleer Santrali’ni savunan, üçü ise karşı çıkan 4 bilim insanına da makale yazdırılmıştır.

Yaklaşık bir buçuk yıllık bir zaman dilimi içinde farklı zamanlarda konuyla ilgili 
yayınlanan köşe yazılarının sadece iki tanesinde egemen söylem üretilmiş, onun dışındakilerin büyük çoğunluğu nükleer enerjiye, ekonomik nedenleri, Çernobil kazasını ve nükleer güvenlik konusunu gerekçe göstererek karşı çıkmıştır. Bu köşe yazılarında nükleer karşıtlarının varlığından söz edilmekte, az da olsa Greenpeace ve onun gibi nükleer karşıtı hareketin unsurlarının temsiliyetine rastlanmaktadır ve yazılarda nükleer karşıtlarına dair olumsuz bir imaj üretilmemekte; aksine itibarları arttırılmaktadır.

Dolayısıyla söylenebilir ki; gazetenin iddia ettiği gibi nükleer ihalenin iptaline giden yolda haberlerin olmasa da köşe yazılarının, hatta sadece bir köşe yazısının bile iptale katkısı olmuş olabilir.

\section{Sonuç}

Toplumun büyük kesiminin elit bir azınlık tarafından nasıl yönetildiğiyle ilgilenen Gramsci'nin hegemonya kuramına göre devlet, “zor” ve "rıza” kavramlarının birlikteliğinden oluşur ve hatta devlet zorun ardından halkın rızasını alabildiği ölçüde başarılı olur; halkın üzerindeki hegemonyasını yani ideolojik ve kültürel kontrolünü kurar. O halde elit azınlığın hegemonyasının kurulması için halkın rızasını sağlayacak araçlara ihtiyaç vardır ki; bunlar aile, okul, kilise ve medya gibi vs. gibi kurumlar olarak sıralanır. Bu kurumlar üzerinden "organik aydınlar” olarak tanımlanan din görevlileri, öğretmenler, gazeteciler vs. eliyle (liberal kapitalist devletlerde milliyetçi sağ) ideoloji, kültür, ahlak kuralları gibi topluma egemen olması istenen bütün değerler sistemi yayılır. Alternatif değerler sistemi ise görmezden gelmek, bu düşünceyi savunanları itibarsızlaştırmak ya da bu düşünceye karşı açıktan savaş açmak gibi yöntemlerle yok edilmeye çalışılır.

Egemen sınıfın iktidarının sürdürülmesi için hegemonyanın yeniden ve yeniden üretilmesi gerekmektedir ve bu noktada medya, "en mahir" kurum olarak ortaya çıkmaktadır. Egemen ideolojiye, yapıya ve değerlere karşı olan her türlü ideolojiye, yapıya ve değerlere karşı olan medya, haber üretimini egemen sınıfın bakış açısıyla yapar.

Medyanın toplumsal iktidar yapılarını üretmekteki rolü konusunda Teun Adrian van Dijk da Gramsci ile benzer düşünmektedir. van Dijk’a göre medya, seçkinlerin sözcüsü değil, simgesel boyutunu yönettiği toplumsal iktidar yapısının kalıtsal bir parçasıdır ve bu haliyle gizli ya da açıktan, egemen söylemi tekrar ve tekrar üretir.

$\mathrm{Bu}$ teorik çerçeveden hareketle çalışma, aslen bir devlet politikası olan nükleer enerjiye geçişin, bu konuda zaman zaman çekincelerini ifade eden dönemin başbakanı ve Demokratik Sol Parti lideri Bülent Ecevit'in eliyle yürütüldüğü 1999-2000 yillarına, Milliyet gazetesi üzerinden odaklanmıştır.

Teun van Dijk'in eleştirel söylem analizi disiplininden yararlanan çalışma değerlendirildiğinde, Milliyet gazetesinin, ihalenin iptali sürecine damgasını vurduğu ve nükleer tehlikeye dikkat çekmek için haberleriyle (toplumsal sorumluluk kuramına ait bir kavram olan) toplumu uyarma görevini yerini getirdiği yolundaki iddiasının, 
sadece (yine toplumsal sorumluluk kuramına ait) tarafsızlık; tüm taraflara haberde eşit mesafede durarak eşit yer verme ilkesi açısından değerlendirildiğinde bile fazlasıyla iddialı olduğu söylenebilir.

Kaldı ki van Dijk'in sunduğu çerçeve ve hegemonya teorisi açısından rahatlıkta belirtilebilir ki; (o dönemin) sosyal demokrat Milliyet gazetesi, (nükleer enerji konusunda çekinceli olduğunu zaman zaman ifade eden sosyal demokrat Başbakan Bülent Ecevit'in nükleer enerjiye dair bu çekincelerini ve nükleer karşıtlarının sesini de açık ve yönlendirme yapmadan okura aktarmak yerine) özellikle başlık ve spotlar üzerinden sadece nükleer enerjiye geçiş doğrultusundaki egemen görüşü görünür kılmak ve böylelikle bu görüşü yeniden üretmek eğilimdedir. Başka bir deyişle, Milliyet gazetesi bu dönemde kendini nükleer enerji konusunda devletin yanında konumlandırmış; destek verse de bu konuda egemen görüşü tam olarak kabul etmeyen hükümetin görüşlerine dair değil, devletin görüşlerine dair halkın rızasını sağlamak amacıyla genellikle manipülasyon ve gölgeleme yollarına başvurarak haber üretiminde bulunmuştur.

$\mathrm{Bu}$ üretim sürecinde, özellikle ekonomi ve politika sayfalarındaki haberlerde, dolayısıyla okurun zihninde, nükleer enerji "gerekli” olarak kodlanmıştır. Okurun zihnindeki "nükleer kaza” imajı doğrudan 1986 Çernobil kazası ile bağlantılı olduğundan, bu haberlerde Çernobil'den söz edilmemekte, hatta bu bağ unutturulmaya çalışılmaktadır. Diğer bir deyişle, gazetede nükleer enerji, Çernobil'den ve nükleer kaza olasılığından hiç bahsetmeden, sadece siyasetçilerin nükleer güvenlik konusunda verdikleri sözleri ve "Nükleere geçmezsek karanlıkta kalırız" şeklindeki halkı tedirgin etmeye ve hatta korkutmaya yönelik tehditkâr argümanları aktararak "gereklilik" üzerinden okurun rızasına sunulmaktadır.

Bu sunumda, Türkiye’deki tüm nükleer karşıtı sesleri bir araya toplayan ve o dönemde oldukça güçlü olan Nükleer Karşıtı Platformun kendisi, eylemleri ve açıklamaları gazete tarafından sistematik olarak görmezden gelinmektedir. Milliyet, nükleer karşıtı ses olarak sadece Greenpeace'i dikkate almıştır, ancak gazetenin Greenpeace'e yaklaşımı da önyargılıdır. Gazete, Greenpeace hakkında "güvenilmez", "kamu düzenini bozan" ve hatta "suçlu" imajı üretmekte ve örgütün Türkiye’de eylem yapan bazı aktivistlerinin yabancı olduğu vurgulanarak okurun zihnindeki "düşman Batı" modelinin haberi anlamlandırmada devreye girmesi sağlanmaktadır. Gazetenin Akkuyu köylüleri hakkında ürettiği imaj ise bazı köylüler "isyankar" olsa bile, "bazı köylüler nükleer enerjiyi istiyor” imajıdır.

Mikro yapı analizinin ortaya koyduğu bir sonuç da gazetede nükleer karşıtı olmayan muhabirlerin mevcudiyetidir. Ancak gazete, bu tip haberlerin sadece başlik ve spotlarına müdahale ederek okuru yönlendirmektedir. Başlık, alt başlık, spot ve haber metni arasında okurun zihnindeki modeller açısından anlam bütünlügünün önemli olmasına rağmen başlık, alt başlık ve spottan yapılan yönlendirme üzerinden de haber metninin taraflı bir göz ile okunması sağlanabilmektedir. Gazetede az da olsa nükleer karşıtı gözle yazılmış haberlere, çıkarılmış spotlara ve atılmış başlıklara da rastlamak mümkündür. Zira, gazeteciler kendilerine yarattıkları hareket alanında 
zaman zaman bu tip haberleri de yayımlayabilmektedir. Fakat egemen görüş gazetede o kadar çok yer kaplamakta ve haber hiyerarşisinde o kadar üst sıralarda kendine yer bulmaktadır ki; küçük bir iki nükleer karşıtı haber, genel toplam içinde pek bir şey ifade etmemekte, okurun zihin dünyasında hiç bir şey değiştirememektedir. Bunun yanı sıra gazete yönetiminin, tıpkı ihalenin iptalinin ardından yaptığı gibi yeri geldiğinde "biz her iki görüşe de yer verdik, topluma karşı sorumluluğumuzu yerine getirdik” diyebilmek için karşıt birkaç habere göz yummuş olması da olasıdır.

Köşe yazılarındaki genel eğilimin ise yazı işlerinin eğiliminden farklı olduğu vurgulanmalıdır. Gazetede bir buçuk yılık bu zaman dilimi içinde Türkiye’nin nükleer enerjiye geçişi ile ilgili en çok yazıyı sekizer yazıyla gazetenin Ankara Temsilcisi Fikret Bila ve Meral Tamer yazmıştır. Bila köşesinde kendi düşüncelerinden çok Başbakan Ecevit'in görüşlerini aktarmıştır ki; bu anlamda gazetede Ecevit'in söylemini üreten tek kişidir. Meral Tamer ise yazılarında nükleer taraftarı argümanları verilerle çürütmüş, nükleer karşıtı argümanları yine verilerle savunmuş ve hükümete ihalenin iptali ve nükleer enerjiden vazgeçilmesi için açık çağrı yapmıştır. Bu köşe yazılarında nükleer karşıtı hareket hakkında olumlu imaj üretilmiştir.

Dolayısıyla gazetenin iddia ettiği gibi nükleer ihalenin iptaline giden yolda haberlerin olmasa bile köşe yazılarının, hatta sadece bir köşe yazısının bile iptale katkısı olasıdır. Ancak eğer nükleer enerjinin iptaline bir köşe yazısının dahi katkısı olmuşsa, o puan gazeteden önce köşe yazarının hanesine yazılmalıdır. Ne var ki bu da ölçülebilir bir durum değildir.

\section{Kaynakça}

Arcan, Hediye Esra. İnsan Hakları ve Medya: ABD Elit Medyasında Türkiye’ye İlişkin İnsan Hakları Haberlerinde Söylem İnşası; The New York Times Gazetesi Örneği. Doktora Tezi, İstanbul Üniversitesi, 2010.

Çakır, Aslı, Pınar Gürleyen ve Faik Uyanık. "Milliyet Gazetesi”. Haber Analizi ve Arşiv incelemeleriyle Türkiyede Dokuz Gazete. Haz., Şengül Özerkan. Ankara: Nobel Yayın Dağıtım, 2009.

Sidar, Cenk. “Türkiye 90’lara Dönmüyor: Bu Zihniyetin Bizi Taşıdığı Yer Çok Daha Karanlık!", Diken, 3 Ağustos 2005, Erişim, 8 Ağustos, 2018. http://www.diken. com.tr/turkiye-90lara-donmuyor-bu-zihniyetin-bizi-tasidigi-yer-cok-dahakaranlik/.

Çevikcan. Serpil, Önder Yılmaz. “Turizm ve Çevre Bakanı'nı Ecevit ikna etti”. Milliyet Gazetesi. 2 Mart 2000.

Dağtaş, Banu. "İngiliz Kültürel Çalışmalarında İdeoloji”. Kurgu Dergisi. 16 (1999): 335-357.

Demir, Vedat. Medya Etiği. İstanbul: Beta Yayınları, 2006.

Demir, Vedat. Türkiyede Medya Siyaset İlişkisi. İstanbul: Beta Yayınları, 2007.

van Dijk, Teun Adrianus. News As Discourse. New Jersey: Lawrance Erlbaum Associates, 1988. 
van Dijk, Teun Adrianus. "Social Cognition and Discourse". Handbook of Language and Social Psychology. Haz., H. Giles ve W.P. Robinson. New York: John Wiley \& Sons, 1990.

van Dijk, Teun Adrianus. "The Interdisciplinary Study of News As Discourse". Handbook of Qualitative Methods in Mass Communication Research. Haz., K. Bruhn-Jensen ve N. Jankowksi. Londra: Routledge, 1991.

van Dijk, Teun Adrianus. "The Mass Media Today: Discourse of Domination or Diversity?". Javnost-The Publlic; Journal of the European Institute for Communication and Culture. 2 (1995): 27-45.

van Dijk, Teun Adrianus. "Opinions and Ideologies in The Press". Approaches to Media Discourse. Haz., Allan Bell ve Peter Garrett. Oxford: Blackwell, 1998.

van Dijk, Teun Adrianus. "Handbook of Discourse Analysis". Critical Discourse Analysis. Haz., D. Schiffrin, D. Tannen, E.H. Hamilton. Oxford: Blakwell Publishing, 2003.

van Dijk, Teun Adrianus. "Söylemin Yapıları ve İktidarın Yapıları”. Medya, İktidar, İdeoloji. Çev., Mehmet Küçük. Ankara: Bilim ve Sanat, 2005.

van Dijk, Teun Adrianus. "Discourse and Manipulation”. Discourse \& Society. 17(3): (2006): 359-383.

van Dijk, Teun Adrianus. "A Sociocognitive Approach”. Methods for Critical Discourse Studies. Haz., Ruth Wodak ve Michael Meyer. Londra: Sage, 2015.

Downing, John D.H.. Radikal Medya: Isyancıların İletişimi ve Toplumsal Hareketler. Haz., Ülkü Doğanay. Ankara: İMGE, 2017.

Durna, Tezcan ve Çağla Kubilay. "Söylem Kuramları ve Eleştirel Söylem Çözümlemeleri”. Medyadan Söylemler. Haz., Tezcan Durna. İstanbul: Libra Kitap, 2010.

Gramsci, Antonio. Hapishane Defterleri: Tarih, Politika, Felsefe ve Kültür Sorunları üzerine Seçmeler. Çev., Kenan Somer. İstanbul: Onur Yayınları, 1986.

Güllüoğlu, Özlem. "'Söylen(mey)enin Analizi: Bellona Markasına Yönelik Tüketici Algısı Üzerine Bir Söylem Çözümlemesi”. Yazılı Metin Çözümleme. Haz., Özlem Güllüoğlu. Ankara: Ütopya Yayınevi, 2012.

Hall, Stuart. “Kültür, Medya ve ‘İdeolojik Etki”’. Medya, İktidar, İdeoloji. Çev., Mehmet Küçük. Ankara: Bilim ve Sanat, 2005.

Hardt, Hanno. “'Eleştirelin’ Geri Dönüşü ve Radikal Muhalefetin Meydan Okuyuşu: Eleştirel Teori, Kültürel Çalışmalar ve Amerikan Kitle İletişim Araştırmaları”. Medya İktidar İdeoloji. Çev., Mehmet Küçük. Ankara, Bilim ve Sanat, 2005.

"Hükümette nükleer sorun”. Milliyet Gazetesi, 23 Kasım 1999.

İnal, Ayşe. Haberi Okumak. İstanbul: Timuçin Yayınları, 1996.

İnceoğlu, Yasemin. Nebahat Çomak. Metin Çözümlemeleri. İstanbul: Ayrıntı Yayınları, 2009.

Karacasulu, Nilüfer. "Hegemonik Düzen Tartışmaları ve Eleştirel Görüşler”. Dokuz Eylül Üniversitesi Sosyal Bilimler Enstitüsü Dergisi. 11/4 (2009): 53-71. 
Künar, Arif. "Nükleerli Tarihimiz”. Don Kişotlar Akkuyu'ya Karşı; Anti-nükleer hikayeler. Haz., Arif Künar. Ankara: EMO Yayınları, 2002.

Keskin, Melda. “Akkuyu halk oylaması...”. Don Kişotlar Akkuyu’ya Karşı; Anti-nükleer hikayeler. Haz., Arif Künar. Ankara: EMO Yayınları, 2002.

Moget, G. "Hegemonya". Hapishane Defterleri: Tarih, Politika, Felsefe ve Kültür Sorunları üzerine Seçmeler. Çev., Kenan Somer. İstanbul: Onur Yayınları, 1986, 73-76.

Özemre, Ahmed Yüksel. Ah, Şu Atomdan Neler Çektim!. İstanbul: Pınar Yayınları, 2001.

Özgen, Murat. Gazetecinin Etik Kimliği. İstanbul: Set-Systems, 2006.

Sözen, Edibe. Söylem: Belirsizlik, Mubadele, Bilgi/Güçve Refleksivite. İstanbul: Birleşik Yayınları, 2014.

Uyar, Tanay Sıdkı. "Enerji Sektöründeki karar vericilerle iletişim ve etkileşimler...”. Don Kişotlar Akkuyu'ya Karşı; Anti-nükleer hikayeler. Haz., Arif Künar. Ankara: EMO Yayınları, 2002, 153-155.

Uzun, Ruhdan. İletişim Etiği; Sorunlar ve Sorumluluklar. Ankara: Dipnot Yayınları, 2011.

Yarman, Tolga. Geçmişte ve Bugün Nükleer Enerji Tartışması. İstanbul: Okan Üniversitesi Yayınları, 2010.

Yaylagül, Levent. Kitle İletişim Kuramları; Egemen ve Eleştirel Yaklaşımlar. Ankara: Dipnot Yayınları, 2006.

Yeldan, Erinç. “Türkiye Ekonomisi: Krizin Yapısal Dayanakları”. Birikim Dergisi. 144 (2001):8-13.

Yılmaz, Önder ve Hakan Şanlıtürk. "Nükleer santrale 'evet”. Milliyet Gazetesi. 3 Aralik 1999. 


\section{Ekler:}

Tablo 1. Milliyet'te 11 Ocak 1999-26 Temmuz 2000 arasinda yayımlanan haberler

\begin{tabular}{|c|c|c|c|}
\hline Tarih & Başliklar & Spot / Haber girişi & Sayfa \\
\hline $\begin{array}{l}14 \text { Ocak } \\
1999\end{array}$ & $\begin{array}{l}\text { Üst Başlık: Prof. Vural Altın } \\
\text { radyasyon kazasının nükleer } \\
\text { enerjiye etkisini değerlendiriyor } \\
\text { Başlık: Devlet ilgisiz, halk } \\
\text { bilgisiz }\end{array}$ & & 20 \\
\hline $\begin{array}{l}14 \text { Nisan } \\
1999\end{array}$ & $\begin{array}{l}\text { Başlık: Akkuyu'da nükleer } \\
\text { korku }\end{array}$ & $\begin{array}{l}\text { Akkuyu’da yapılması düşünülen nükleer santralın } \\
\text { riskli fay hatlarının çok yakınında bulunması } \\
\text { yüzünden olası bir depremde tüm Akdeniz } \\
\text { havzasının bundan etkileyeceği, sakat bırakacak } \\
\text { hatta öldürecek radyasyon bulutlarının çevreye } \\
\text { yayılacağı belirtildi. }\end{array}$ & 5 \\
\hline $\begin{array}{l}13 \\
\text { Temmuz } \\
1999\end{array}$ & Başlık: Nükleer referandum & $\begin{array}{l}\text { Türkiye’nin ilk atom santralinim kurulacağı İçel'in } \\
\text { Gülnar ilçesinde Greenpeace tarafından yapılan } \\
\text { referandumda halkın yüzde 84’ü Akkuyu'ya } \\
\text { nükleer santral için karşıt oy kullandı. }\end{array}$ & 3 \\
\hline $\begin{array}{l}1 \\
\text { Ağustos } \\
1999\end{array}$ & $\begin{array}{l}\text { Başlık: Halka "rağmen” } \\
\text { teknoloji? } \\
\text { Alt Başlı: Teknoloji, halkın } \\
\text { talepleri ve çevre koruma } \\
\text { üçgeni Türkiye gündemine } \\
\text { oturuyor }\end{array}$ & $\begin{array}{l}\text { Teknolojik gelişme ve ilerleme, çevreye ve halka } \\
\text { "rağmen" olabilir mi? Bu sorunun en yalın } \\
\text { haliyle hayır. Ama dünyada "teknolojinin çevreyi } \\
\text { mahvetmesine rağmen, hem de halka rağmen } \\
\text { ama "halk için" dayatıldığına o kadar çok örnek } \\
\text { var ki. }\end{array}$ & 21 \\
\hline $\begin{array}{l}20 \text { Ekim } \\
1999\end{array}$ & $\begin{array}{l}\text { Başlık: } 165 \text { metrede eylem } \\
\text { Alt Başlık: Greenpeace } \\
\text { grubu nükleer protesto için } \\
\text { Boğaziçinin çelik kulelerine } \\
\text { tırmandı. }\end{array}$ & $\begin{array}{l}\text { Greenpeace çevre örgütü üyeleri, Boğaziçi } \\
\text { Köprüsü’nün denizden } 165 \text { metre yükseklikteki } \\
\text { çelik kulesine astıkları pankartla, Enerji Bakanı } \\
\text { Cumhur Ersümer ve Akkuyu nükleer santralını } \\
\text { protesto etti. }\end{array}$ & 3 \\
\hline $\begin{array}{l}21 \text { Ekim } \\
1999\end{array}$ & Başlık: Greenpeace’e sınırdışı & $\begin{array}{l}\text { Akkuyu Termik Santralı’nın yapımını protesto } \\
\text { etmek amacıyla Boğaziçi Köprüsü’nde eylem } \\
\text { yapan uluslararası çevre örgütü Greenpeace'in } \\
\text { yabancı uyruklu yedi üyesi dün sınırdışı edildi. }\end{array}$ & 13 \\
\hline $\begin{array}{l}9 \text { Kasim } \\
1999\end{array}$ & $\begin{array}{l}\text { Başlık: Nükleer santralda } 2005 \text { 'i } \\
\text { beklemeli }\end{array}$ & $\begin{array}{l}\text { Türkiye, nükleer enerji santrallarını tartışırken } \\
\text { bilimadamları, kamuoyunun bir çok noktada } \\
\text { yanıltıldığını iddia etti. }\end{array}$ & 7 \\
\hline $\begin{array}{l}23 \\
\text { Kasim } \\
1999\end{array}$ & $\begin{array}{l}\text { Başlık: Nükleer anlaşmazlık } \\
\text { Alt Başlık: Enerji Bakanı } \\
\text { "Türkiye'nin mutlaka bir } \\
\text { nükleer santrala ihtiyacı } \\
\text { var. Koalisyonda mutabakat } \\
\text { arıyoruz" dedi }\end{array}$ & $\begin{array}{l}\text { Akkuyu Santralı projesinde sorun yaşadıklarını } \\
\text { belirten Cumhur Ersümer, "Nükleer santralın } \\
\text { ben çok sağlıklı ve çevre dostu bir enerji kaynağı } \\
\text { olduğunu düşünüyorum. Ülkemizin çevresi } \\
\text { bunlarla dolu. } 10 \text { şiddetinde depreme dayanıklı } \\
\text { yapıyorlar” diye konuştu. } \\
\text { Hükümet ortaklarıyla yılın sonuna kadar bu } \\
\text { konuda kesin bir karar verilmesi gerektiğini } \\
\text { de vurgulayan Bakan ekliyor: "Aksi takdirde } \\
\text { uluslararası alanda inandırıcılığımızı yitireceğiz. } \\
\text { Bundan sonra kimse Türkiye’ye santral teklifi } \\
\text { vermez." }\end{array}$ & 1 \\
\hline
\end{tabular}




\begin{tabular}{|c|c|c|c|}
\hline $\begin{array}{l}23 \\
\text { Kasim } \\
1999\end{array}$ & $\begin{array}{l}\text { Başlık: Hükümette nükleer } \\
\text { sorun }\end{array}$ & $\begin{array}{l}\text { Akkuyu Nükleer Santralı projesi konusunda } \\
\text { hükümette sorun yaşandığını ifade eden } \\
\text { Başbakan Yardımcısı Cumhur Ersümer, «Eğer } \\
\text { Türkiye bu nükleer santralın yapımına bugün } \\
\text { de karar vermezse Enerji Bakanı olarak bunu } \\
\text { 'biz nükleer santral yapmak istemiyoruz' olarak } \\
\text { algılarım” dedi. }\end{array}$ & 11 \\
\hline $\begin{array}{l}1 \text { Aralık } \\
1999\end{array}$ & Başlık: Liderler enerji zirvesinde & $\begin{array}{l}\text { Başbakan Bülent Ecevit, Başbakan Yardımcısı } \\
\text { Devlet Bahçeli ve ANAP lideri Mesut Yılmaz } \\
\text { yarın bir araya gelerek Türkiye’nin enerji } \\
\text { politikasını görüşecek. }\end{array}$ & 15 \\
\hline $\begin{array}{l}3 \text { Aralık } \\
1999\end{array}$ & $\begin{array}{l}\text { Başlık: Nükleer kararı } \\
\text { Alt Başlık: }\end{array}$ & $\begin{array}{l}\text { Enerji sorununun tartışıldığı koalisyon liderleri } \\
\text { zirvesinde, Türkiye’de nükleer santral yapılması } \\
\text { kabul edildi. Başbakan Bülent Ecevit, Akkuyu } \\
\text { Nükleer santralıyla ilgili olarak, "Bu ay içinde bir } \\
\text { sonuca varılacak" dedi. Cumhurbaşkanı Demirel } \\
\text { de santralın zorunlu olduğunu dile getirdi: } \\
\text { "Nükleer teknoloji olmazsa çağdışı kalırız.' }\end{array}$ & 1 \\
\hline $\begin{array}{l}3 \text { Aralik } \\
1999\end{array}$ & $\begin{array}{l}\text { Başlık: Nükleer santrala "evet" } \\
\text { Alt Başlık: }\end{array}$ & $\begin{array}{l}\text { Nükleer santral projesi için liderler zirvesinden } \\
\text { olumlu karar çıtı. Demirel "Bu iş olmazsa çağın } \\
\text { gerisinde kalırız” dedi. }\end{array}$ & 11 \\
\hline $\begin{array}{l}4 \text { Aralık } \\
1999\end{array}$ & $\begin{array}{l}\text { Üst Başlı: Milliyet-İTÜ } \\
\text { işbirliği; } 60 \text { bilim adamının } \\
\text { gündemi Türkiye } \\
\text { Başlık: Nükleer deprem } \\
\text { Alt Başlık: İstanbulıda Akkuyu } \\
\text { Santralı tartışılırken, Avrupa'dan } \\
\text { uyarı geldi }\end{array}$ & $\begin{array}{l}\text { Deprem uzmanları nükleer santral konusunda } \\
\text { görüş ayrılığına düştü. } \\
\text { Prof. Dr. Jean Bardet (California Üniversitesi): } \\
\text { Fay hattında yapılacak böyle bir tesis çok riskli. } \\
\text { Fayın aktivitesinin ölçülmesi gerekir. Ben şiddetle } \\
\text { karşıyım. } \\
\text { Tayfun Amur (Uluslararası Dünya Danışmanları): } \\
\text { Türkiyede nükleer problem çözecek endüstri yok. } \\
\text { Nükleer santralda soğutma da önemli. Güney’in } \\
\text { suyu sıcak. } \\
\text { Prof. Dr. Mehmet Çelebi (ABD Yer Bilimleri): } \\
\text { Akkuyu fay hattında değil. İyi mühendislik } \\
\text { görmüş yerler dayanıklı oluyor. Endişem yok. }\end{array}$ & 1 \\
\hline $\begin{array}{l}4 \text { Aralik } \\
1999\end{array}$ & Başlık: Nükleerde fay endişesi & $\begin{array}{l}\text { Türkiye’nin nükleer santral için start vermesi } \\
\text { tartışma yarattı. İTÜ-Milliyet işbirliğiyle } \\
\text { düzenlenen konferansa katılan deprem uzmanları } \\
\text { Akkuyu için kaygıll. }\end{array}$ & 17 \\
\hline $\begin{array}{l}6 \text { Aralik } \\
1999\end{array}$ & $\begin{array}{l}\text { Üst Başlık: Prof. Jean-Pierre } \\
\text { Bardet } \\
\text { Başlık: Toprağa bakmak lazım } \\
\text { Alt Başlık: }\end{array}$ & $\begin{array}{l}\text { Kaliforniya Teknik Üniversitesi öğretim üyesi } \\
\text { Prof. Dr. Jean-Pierre Bardet, Akkuyu’ya nükleer } \\
\text { santral yapımına karşı çıkarak “Deprem sırasında } \\
\text { yer hareketleri konusunda bilinmeyen çok şey var. } \\
\text { Faya yakın olmak büyük risk taşıyor. Akkuyu'da } \\
\text { yed hareketlerini değerlendirmeye ihtiyaç var” } \\
\text { dedi. }\end{array}$ & 17 \\
\hline
\end{tabular}




\begin{tabular}{|c|c|c|c|}
\hline $\begin{array}{l}6 \text { Aralik } \\
1999\end{array}$ & $\begin{array}{l}\text { Üst Başlık: Köylü Ankara’ya } \\
\text { "Ayaklanacağı, haberiniz } \\
\text { olsun” mesajı yolluyor } \\
\text { Başlık: Akkuyu karakuyu belli } \\
\text { olacak! } \\
\text { Alt Başlık: }\end{array}$ & $\begin{array}{l}\text { Geçtiğimiz haftaki elektrik kesintilerinin } \\
\text { ardından hükümet ortakları "radyasyonlu } \\
\text { müjde”yi verdiler: Akkuyu Nükleer Santralının } \\
\text { ihalesi bu ay sonuna kadar açllacak! Yaklaşık } \\
25 \text { yıldır süren yılan hikayesinin "mutsuz son”u } \\
\text { hakkında yörede yaşayanların ne düşündügünü } \\
\text { öğrenmek için Mersin Büyükeceli beldesine } \\
\text { uzandık. }\end{array}$ & 17 \\
\hline $\begin{array}{l}6 \text { Aralik } \\
1999\end{array}$ & $\begin{array}{l}\text { Üst Başlık: MHP Kayseri } \\
\text { Milletvekili Gül'den bilim } \\
\text { adamlarına: } \\
\text { Başlık: Erken öten horozun } \\
\text { kafası kesilir } \\
\text { Alt Başlık: }\end{array}$ & $\begin{array}{l}\text { MHP Kayseri milletvekili Mustafa Gül, “Akkuyu } \\
\text { fay hattında” diyen bilim adamlarına yanıt } \\
\text { verirken "Erken öten horozun kafası kesilir” dedi. }\end{array}$ & 17 \\
\hline $\begin{array}{l}17 \\
\text { Aralık } \\
1999\end{array}$ & $\begin{array}{l}\text { Başlık: Türk’ün radyasyonla } \\
\text { imtihanı }\end{array}$ & $\begin{array}{l}\text { Geçen hafta İstanbul'da bir hurdalıkta yaşanan } \\
\text { nükleer kaza radyasyon karşısında ikinci sınavı } \\
\text { vermemize yol açtı. Ancak tıpkı Çernobil } \\
\text { vakasında olduğu gibi yine sınıfta kaldık! }\end{array}$ & 5 \\
\hline $\begin{array}{l}19 \\
\text { Aralık } \\
1999\end{array}$ & $\begin{array}{l}\text { Üst Başlık: Yeşil Barış’ın en aktif } \\
\text { üyesi Melda Keskin } \\
\text { Başlık: İki eli suçluların } \\
\text { yakasında } \\
\text { Alt Başlık: }\end{array}$ & $\begin{array}{l}\text { Melda Keskin, Greenpeace Akdeniz ofisi-Türkiye } \\
\text { bölümünde enerji kampanyası sorumlusu olarak } \\
\text { çalışıyor. Keskin, çevreyi kirletenlerin "çevreci } \\
\text { kesilmesinden" yakınırken herkesi tepki vermeye } \\
\text { çağırıyor. }\end{array}$ & $\begin{array}{l}4 \\
\text { Pazar } \\
\text { eki }\end{array}$ \\
\hline $\begin{array}{l}19 \\
\text { Aralık } \\
1999\end{array}$ & $\begin{array}{l}\text { Başlık: Çevreci Al Gore nükleer } \\
\text { santral için lobide } \\
\text { Alt Başlık: Akkuyu Nükleer } \\
\text { Santrali ihalesinin ABD`nin } \\
\text { içinde bulunduğu konsorsiyuma } \\
\text { verilmesi konusunda ABD } \\
\text { Başkan Yardımcısı Al Gore Türk } \\
\text { Hükümetine mektup yazdı. }\end{array}$ & $\begin{array}{l}\text { Türkiye’nin } 30 \text { yıldır tartıştığı nükleer enerji } \\
\text { konusunda dev adım için geri sayım başladı. } \\
\text { İhaleye giren ve teklifi kabul edilen ABD-Japonya, } \\
\text { Fransa-Almanya ile Kanada firmalarından } \\
\text { hangisinin Akkuyu Nükleer Santralı'nı yapacağı } \\
\text { önümüzdeki günlerde belli olacak. }\end{array}$ & \\
\hline $\begin{array}{l}20 \\
\text { Aralık } \\
1999 \\
\end{array}$ & $\begin{array}{l}\text { Başlık: Doktorlar nükleer } \\
\text { santrala karşı }\end{array}$ & $\begin{array}{l}\text { İstanbul Tabip Odası, Akkuyu'da yapılmak istenen } \\
\text { nükleer santrala karşı olduğunu açıkladı. }\end{array}$ & 14 \\
\hline $\begin{array}{l}29 \\
\text { Aralik } \\
1999\end{array}$ & Başlık: Akkuyu'da karar yok & $\begin{array}{l}\text { Koalisyonu oluşturan üç parti liderinin dün } \\
\text { akşam Meclis’te yaptığı toplantıda dört konu } \\
\text { görüşüldü. Liderler nükleer santral konusunun } \\
\text { yanı sıra türban, asgari ücret ve tahkimi ele aldı. }\end{array}$ & 19 \\
\hline $\begin{array}{l}30 \\
\text { Aralık } \\
1999\end{array}$ & $\begin{array}{l}\text { Başlık: MGK'dan nükleere vize } \\
\text { Alt Başlık: }\end{array}$ & $\begin{array}{l}\text { Cumhurbaşkanı Süleyman Demirel başkanlığında } \\
\text { dün Çankaya Köşkü’nde yüzyılın son toplantısını } \\
\text { yapan Milli Güvenlik Kurulu (MGK), Akkuyu’ya } \\
\text { nükleer santral yapılmasına vize verdi. }\end{array}$ & 19 \\
\hline $\begin{array}{l}22 \text { Ocak } \\
2000\end{array}$ & $\begin{array}{l}\text { Başlık: ABD nükleer santral için } \\
\text { bastırıyor }\end{array}$ & $\begin{array}{l}\text { Katrilyonluk Akkuyu Nükleer Santrali için } \\
\text { dördüncü kez geri sayım başlarken Ankara'da } \\
\text { olağanüstü bir “lobi” faaliyeti yürütüldüğ̈ü ortaya } \\
\text { çıktı. }\end{array}$ & 7 \\
\hline
\end{tabular}




\begin{tabular}{|c|c|c|c|}
\hline $\begin{array}{l}15 \text { Şubat } \\
2000\end{array}$ & $\begin{array}{l}\text { Başlık: Akkuyu'da katrilyonluk } \\
\text { rakamlar savaşıyor... }\end{array}$ & $\begin{array}{l}\text { Akkuyu Nükleer Santralıının yapımına talip } \\
\text { üç konsorsiyum arasında yapılacak seçim için } \\
\text { son } 15 \text { güne girildi. Son olarak Cumhurbaşkanı } \\
\text { Süleyman Demirel, "Hangi teknoloji olacağına } \\
\text { karar verilecek" derken ihalede ABD, Avrupa } \\
\text { ve Kanada konsorsiyumlarının verdikleri } \\
\text { katrilyonluk rakamlar savaşıyor. }\end{array}$ & 9 \\
\hline $\begin{array}{l}18 \text { Şubat } \\
2000\end{array}$ & $\begin{array}{l}\text { Başlık: Nükleer santral "su } \\
\text { koyverdi” } \\
\text { Alt Başlık: Nükleer santral } \\
\text { su koyverdi «Çok güvenli» } \\
\text { iddiasılyla Türkiye`de de yapımı } \\
\text { düşünülen ABD〉deki nükleer } \\
\text { santrallardan biri, buhar } \\
\text { jeneratöründe radyoaktif sızıntı } \\
\text { şüphesiyle kapatıldı. }\end{array}$ & $\begin{array}{l}\text { ABD’nin New York kenti, önceki gün korkunç } \\
\text { bir panikle uyandı. } 15 \text { milyonu bulan nüfusuyla } \\
\text { dünyanın ve ABD’nin en büyük metropollerinden } \\
\text { olan kentte yaşayanlar, sadece } 55 \text { kilometre } \\
\text { uzaklıktaki bir nükleer santralın kapatıldığı } \\
\text { haberiyle neye uğradıklarını şaşırdı. }\end{array}$ & 3 \\
\hline $\begin{array}{l}1 \text { Mart } \\
2000\end{array}$ & $\begin{array}{l}\text { Başlık: } 6.5 \text { katrilyonluk pazarlık } \\
\text { Alt Başlık: Türkiye bugün } \\
\text { açılanması beklenen nükleer } \\
\text { santral ihalesiyle birlikte, } \\
11 \text { milyar dolarlık pazarlığa } \\
\text { oturmaya hazırlanıyor. }\end{array}$ & $\begin{array}{l}\text { Başbakan Bülent Ecevit başkanlığındaki hükümet, } \\
\text { yaklaşık } 11 \text { milyar dolarlık uluslararası ihalelerle } \\
\text { ilgili karar vermeye hazırlanıyor. Milletvekilleri } \\
\text { ve stratejistler ihaleler karşılığında "ödün” } \\
\text { koparılabileceği uyarısında bulundu. }\end{array}$ & 10 \\
\hline $\begin{array}{l}2 \text { Mart } \\
2000\end{array}$ & $\begin{array}{l}\text { Başlık: İki nükleer karar } \\
\text { Alt Başlık: 1-Santral Akkuyu’ya } \\
\text { kurulacak. 2-İhaleyi siyaset } \\
\text { değil, teknik kazanacak. }\end{array}$ & $\begin{array}{l}\text { İhalede yetki TEAŞ’ta: Bakanlar Kurulu, dört } \\
\text { kez ertelenen Akkuyu Nükleer Santralına son } \\
\text { onayı verdi. Yetki veren TEAŞ, } 10 \text { gün içinde } \\
\text { ihaleye giden firmalarla masaya oturacak. } \\
\text { Santral yapımına talep üç konsorsiyum şöyle: } \\
\text { Westinghouse-Mitsubishi (ABD-Japonya), } \\
\text { A-ECL (Kanada), NPI (Alman-Fransız) } \\
\text { Ecevit: Uzmanlar seçecek: Toplantıda ihaleyi alan } \\
\text { firmanın tamamen teknik ölçülerle seçilmesi } \\
\text { kararlaştırıldı. Başbakan Ecevit “Teklif veren } \\
\text { ülkelerle ilişkilerimiz çok iyi. Bu nedenle siyasi } \\
\text { ölçü kullanmamız yanlış olur. Seçimi ilgili } \\
\text { kurumların uzmanları yapacak” dedi. }\end{array}$ & 1 \\
\hline $\begin{array}{l}2 \text { Mart } \\
2000\end{array}$ & $\begin{array}{l}\text { Başlık: Nükleere yeşil ışık } \\
\text { Alt Başlık: Bakanlar Kurulu, } \\
\text { üç saatlik toplantının ardından } \\
\text { Akkuyu Nükleer Santralinin } \\
\text { ihalesi için TEAŞ’a yetki verdi. }\end{array}$ & $\begin{array}{l}\text { Bakanlar Kurulu, dört kez ertelenen Akkuyu } \\
\text { Nükleer Santrali ihalesinin tamamlanması için } \\
\text { TEAŞ’a yetki verdi. TEAŞ’ın } 10 \text { gün içinde ihaleye } \\
\text { giren firmalarla teklifleri doğrultusunda masaya } \\
\text { oturacağı bildirildi. }\end{array}$ & 16 \\
\hline $\begin{array}{l}2 \text { Mart } \\
2000\end{array}$ & $\begin{array}{l}\text { Başlık: Turizm ve Çevre } \\
\text { Bakanı'nı Ecevit ikna etti }\end{array}$ & $\begin{array}{l}\text { Bakanlar Kurulunda santrala itiraz eden Turizm } \\
\text { ve Çevre bakanlarını Başbakan Ecevit "Ben de } \\
\text { bazı tereddütler taşıyordum ancak yaptığım } \\
\text { görüşmelerden sonra tereddütüm kalmadı" } \\
\text { sözleriyle ikna etti. }\end{array}$ & \\
\hline
\end{tabular}




\begin{tabular}{|c|c|c|c|}
\hline $\begin{array}{l}3 \text { Mart } \\
2000\end{array}$ & $\begin{array}{l}\text { Başlık: Köyde atom savaşı } \\
\text { Alt Başlık: Mersin Akkuyu'da } \\
\text { baba-oğul arasına nükleer } \\
\text { santral girdi... }\end{array}$ & $\begin{array}{l}\text { Hükümetin nükleer kararı, Silifke Büyükeceli’ye } \\
\text { bomba gibi düştü. Akkuyu'daki } 5 \text { bin nüfuslu } \\
\text { beldenin çoğu sakini, santrala karşı. Cephenin } \\
\text { önderi muhtar Kemal Budak. Ortak görüşleri: } \\
\text { "Hava, su, toprak, kirlenecek, tek geçim } \\
\text { kaynağımız çiftçilik ölecek. Tarla ve seralarımız } \\
\text { zehir dolacak." Narenciye ve seracılıkla geçinen } \\
\text { köylüleri , nükleer atıklar ve turizmin geleceği de } \\
\text { düşündürüyor. İşsizlere göre ise, santral “ekmek } \\
\text { kapısı “ olacak. Gençler "İnşaat } 6.5 \text { yıl sürecekmiş. } \\
\text { İşsizlik kalmayacak” diyor. }\end{array}$ & 1 \\
\hline $\begin{array}{l}3 \text { Mart } \\
2000\end{array}$ & $\begin{array}{l}\text { Başlık: TEAŞ on gün içinde } \\
\text { seçimini açıklayacak }\end{array}$ & $\begin{array}{l}\text { Başbakan Ecevit’in “siyasi karar değil teknik karar } \\
\text { verilecek" diyerek son noktayı koyduğu santrala } \\
\text { ilişkin olan } 1997 \text { yılından bu yana çalışan TEAŞ, } \\
10 \text { içinde son kararı verecek. }\end{array}$ & 10 \\
\hline $\begin{array}{l}3 \text { Mart } \\
2000\end{array}$ & Başlık: Lobiler çarpışıyor & $\begin{array}{l}\text { Akkuyu Nükleer Santrali için teklif veren üç } \\
\text { konsorsiyumun projeleri ve lobi faaliyetleri şöyle: }\end{array}$ & 10 \\
\hline $\begin{array}{l}3 \text { Mart } \\
2000\end{array}$ & Başlık: Köylüler bölündü & $\begin{array}{l}\text { Bakanlar Kurulu'nun önceki gün yaptığı üç } \\
\text { saatlik toplantının ardından } 24 \text { yıldan beri rafta } \\
\text { bekleyen Akkuyu'da yapılacak nükleer santral ile } \\
\text { ilgili karar verildi. TEAŞ } 10 \text { gün sonra ihaleye en } \\
\text { uygun teklifi veren üç şirketle masaya oturacak ve } \\
\text { nükleer santralın yapımı için düğmeye basılacak. }\end{array}$ & 10 \\
\hline $\begin{array}{l}9 \text { Mart } \\
2000\end{array}$ & $\begin{array}{l}\text { Başlık: Atina, Akkuyu santralına } \\
\text { karşı }\end{array}$ & $\begin{array}{l}\text { Yunanistan Dışişleri Bakanı Yorgo Papandreu’nun } \\
\text { Dışişleri Bakanı İsmail Cem`i telefonla arayarak, } \\
\text { Akkuyu nükleer santralını konu alan endişesini } \\
\text { de dile getirdiği bildirildi. }\end{array}$ & 15 \\
\hline $\begin{array}{l}10 \text { Mart } \\
2000\end{array}$ & $\begin{array}{l}\text { Başlık: Nükleerde firmalar } \\
\text { kapıştı }\end{array}$ & $\begin{array}{l}\text { Nükleer santral ihalesine katılan üç grup } \\
\text { arasındaki çekişmeler nedeniyle ihalenin } \\
\text { aksayabileceği bildirildi. } 4 \text { milyar dolar } \\
\text { değerindeki ihaleye katılan ABD ve Kanadalı } \\
\text { firmalar, üçüncü rakipleri Alman-Fransız } \\
\text { ortaklığı NPI'nın teklifinde bazı "arızalar" } \\
\text { bulunduğunu öne sürerek, "NPI kazanırsa yasal } \\
\text { yollara başvururuz" uyarısı yaptı. }\end{array}$ & 9 \\
\hline $\begin{array}{l}5 \text { Nisan } \\
2000\end{array}$ & $\begin{array}{l}\text { Başlık: Nükleere hazine freni } \\
\text { Alt Başlık: Hazinenin } \\
\text { enflasyonu düşürme } \\
\text { programına aykırı olduğu için } \\
\text { garanti vermediği nükleer } \\
\text { santral ihalesinin ertelenmesi } \\
\text { gündemde. }\end{array}$ & $\begin{array}{l}\text { Hazine Müsteşarlığı yaklaşık } 4 \text { milyar dolarlık } \\
\text { Akkuyu Nükleer Santralı Projesine karşı çıktı. } \\
\text { Bunun üzerine sonucu } 7 \text { Nisan`da açıklanması } \\
\text { gereken aç konsorsiyumun yarıştığı ihalenin bir } \\
\text { yıl daha ertelenmesi ihtimali doğdu. }\end{array}$ & 7 \\
\hline $\begin{array}{l}8 \text { Nisan } \\
2000\end{array}$ & $\begin{array}{l}\text { Başlık: Nükleerde 5. erteleme } \\
\text { Alt Başlık: Hazinenin enflasyon } \\
\text { programına uymadığ } \\
\text { gerekçesiyle garanti vermediği } \\
\text { nükleer santral ihalesi } 21 \\
\text { Nisan'a ertelendi. }\end{array}$ & $\begin{array}{l}\text { Sonucu dün açıklanması gereken, üç } \\
\text { konsorsiyumun yarıştığı Akkuyu Nükleer Santralı } \\
\text { ihalesi ertelendi. Kesin kararın } 21 \text { Nisan'da } \\
\text { açıklanması bekleniyor. }\end{array}$ & 15 \\
\hline $\begin{array}{l}8 \text { Nisan } \\
2000\end{array}$ & Başlık: 40 çevreci göz altında & $\begin{array}{l}\text { İçel>in Gülnar ilçesi Akkuyu mevkiinde yapılması } \\
\text { planlanan nükleer santrali protesto için bildiri } \\
\text { dağıtmak isteyen } 500 \text { çevreciye polis müdahale } \\
\text { etti, } 40 \text { çevreci göz altına alındı. }\end{array}$ & 15 \\
\hline
\end{tabular}




\begin{tabular}{|c|c|c|c|}
\hline $\begin{array}{l}8 \text { Nisan } \\
2000\end{array}$ & $\begin{array}{l}\text { Başlık: Türkiye nükleerde } \\
\text { gecikti }\end{array}$ & $\begin{array}{l}\text { Mersin Akkuyu'ya yapılması planlanan nükleer } \\
\text { santrala yönelik tartışma ve tepkiler sürerken } \\
\text { feshedilen SHP’nin onursal genel başkanı Erdal } \\
\text { İnönü, Türkiye'nin nükleer santraller konusunda } \\
\text { geç kaldığını söyledi. }\end{array}$ & 15 \\
\hline $\begin{array}{l}9 \text { Nisan } \\
2000\end{array}$ & $\begin{array}{l}\text { Üst Başlık: Nükleer fiyaskonun } \\
\text { perde arkası } \\
\text { Başlık: Skandal ihale } \\
\text { Alt Başlık: Bakanlar } \\
\text { Kurulu'ndan 'nihai karar' yetkisi } \\
\text { alan TEAŞ, teklifi şartnameye } \\
\text { uymayan Alman-Fransız } \\
\text { ortaklığını seçince işler karıştı... }\end{array}$ & $\begin{array}{l}\text { Teminat mektubu yok: Akkuyu Nükleer Santralı } \\
\text { için hazırlanan ihale şartnamesi projenin } \\
\text { finansmanını tümüyle üretici firmaya yüklüyor. } \\
\text { Ayrıca bir Türk bankasından da teminat mektubu } \\
\text { alması gerekiyor. TEAŞ’ı "en ucuz teklif” diye } \\
\text { kabul ettiği konsorsiyum ise böyle bir teminat } \\
\text { mektubu sunmadı. } \\
\text { "Referansı da yok": İhaleye katılan ABD-Japonya } \\
\text { konsorsiyumu ile Kanada şirketi, Alman-Fransız } \\
\text { ortaklığının bugüne dek TEAŞ’n istediği çapta } \\
\text { bir santral yaptı̆̆ına dair referansını olmadı̆̆ını } \\
\text { bildirdi. Ve ihalenin sonucu beşinci kez ertelendi. }\end{array}$ & 1 \\
\hline $\begin{array}{l}9 \text { Nisan } \\
2000\end{array}$ & $\begin{array}{l}\text { Başlık: Nükleeri karıştıran } \\
\text { mektup } \\
\text { Alt Başlık: Hazinenin enflasyon } \\
\text { düşürme programına aykırı } \\
\text { olduğu için garanti vermediği } \\
\text { nükleer santral ihalesinin } \\
\text { ertelenmesi gündemde. }\end{array}$ & $\begin{array}{l}\text { Türkiye Elektrik Üretim ve İletim AŞ’nin (TEAŞ) } \\
\text { Akkuyu Nükleer Santralı ihalesinde seçimini } \\
\text { Alman-Fransız konsorsiyumundan yana yaptığı } \\
\text { ancak bu konsorsiyumun teklifinin şartnameye } \\
\text { uymadığı iddia edildi. }\end{array}$ & 7 \\
\hline $\begin{array}{l}11 \text { Nisan } \\
2000\end{array}$ & $\begin{array}{l}\text { Başlık: Baloncu kaçtı kurtuldu } \\
\text { eylemciler yakalandı }\end{array}$ & $\begin{array}{l}\text { Akkuyu’yu protesto için balon uçuruldu. Uçup } \\
\text { kurtulan iki çevreci balonu söndürüp evlerine } \\
\text { döndü. Gözaltına alınan } 9 \text { kişi ise akşam } \\
\text { saatlerinde serbest bırakıldı. }\end{array}$ & 3 \\
\hline $\begin{array}{l}12 \text { Nisan } \\
2000\end{array}$ & $\begin{array}{l}\text { Başlık: Konsorsiyumlar tahkime } \\
\text { hazırlanıyor } \\
\text { Alt Başlık: Siemens, Yılmaz'ı } \\
\text { devreye sokmaya çalışırken DSP } \\
\text { sıkıntılı }\end{array}$ & $\begin{array}{l}\text { Akkuyu nükleer ihalesine katılan } \\
\text { konsorsiyumların, } 21 \text { Nisan'da ertelenmesi veya } \\
\text { iptal kararı verilmesi durumunda "tahkim" } \\
\text { başvurusu hazırlığı içinde olduğu, Fransı-Alman } \\
\text { grubu NPI’nın ise ANAP lideri Mesut Yılmaz’ı } \\
\text { devreye sokmaya çalıştığı öne sürüldü. }\end{array}$ & 12 \\
\hline $\begin{array}{l}16 \text { Nisan } \\
2000\end{array}$ & Başlık: Uçanla kaçana ceza yok! & $\begin{array}{l}\text { Akkuyu’da kurulması planlanan nükleer santralı } \\
\text { protesto etmek için Sultanahmet Meydanı’nda } \\
\text { eylem yapan Greenpeace üyelerinden göz altına } \\
\text { alınan dokuz Türk hakkında "izinsiz gösteri” } \\
\text { yaptıkları gerekçesiyle üç yıla kadar hapis cezası } \\
\text { istemiyle dava açıldı. Eylem sırasında "Stop } \\
\text { Akkuyu" yazılı balonla gökyüzüne havalanan } \\
\text { Fransız v Avusturyalı iki uyanık eylemci ise } \\
\text { yargılanmaktan kurtuldu. }\end{array}$ & 3 \\
\hline $\begin{array}{l}22 \text { Nisan } \\
2000\end{array}$ & $\begin{array}{l}\text { Başlık: Nükleer üç ay erteleme } \\
\text { Alt Başlık: }\end{array}$ & $\begin{array}{l}\text { Üç konsorsiyumun yarıştığı Akkuyu Nükleer } \\
\text { Santra İhalesi altıncı kez uzatıldı. İhaleye katılan } \\
\text { konsorsiyumlardan } 24 \text { Temmuz } 2000 \text { tarihine } \\
\text { kadar opsiyonlarını uzatmaları istendi. }\end{array}$ & 7 \\
\hline
\end{tabular}




\begin{tabular}{|c|c|c|c|}
\hline $\begin{array}{l}9 \\
\text { Temmuz } \\
2000\end{array}$ & $\begin{array}{l}\text { Başlık: Orası Almanya burası } \\
\text { Türkiye } \\
\text { Alt Başlı: Almanya'nın } \\
\text { ülkedeki nükleer santralleri } \\
\text { kapatma kararı, bir Alman } \\
\text { firması olan Siemens'in } \\
\text { Türkiye'deki santral ihalesine } \\
\text { girmesini engellemedi. }\end{array}$ & $\begin{array}{l}\text { Alman hükümetinin, ülkedeki nükleer } \\
\text { santralların tümünü kapatma kararına rağmen } \\
\text { Alman orijinli Siemens, hazinenin kredi } \\
\text { güvencesi vermemesi nedeniyle ertelenen, } 24 \\
\text { Temmuz'da yinelenecek Akkuyu Nükleer Santral } \\
\text { ihalesine katılacak. }\end{array}$ & 9 \\
\hline $\begin{array}{l}12 \\
\text { Temmuz } \\
2000\end{array}$ & $\begin{array}{l}\text { Üst Başlık: Ankara: Enerji açı̆̆ı } \\
\text { var, santral şart... İstanbul: Yalan } \\
\text { Başlık: Nükleer çatışma çıktı } \\
\text { Alt Başlık: }\end{array}$ & $\begin{array}{l}\text { Başbakan’a TAEK raporu: Devlet Bakanı } \\
\text { Gaydalı'nın Başbakan’a ve kabine üyelerine } \\
\text { sunulmak üzere TAEK’e hazırlattığı raporda, } \\
\text { toplumun yanlış yönlendirildiği, enerji açı̆̆ının } \\
\text { ancak nükleer santraller ile kapatılabileceği } \\
\text { vurgulandı. "Almanya'nın kapatma kararı } \\
\text { aldatmacadır” denildi. } \\
\text { Almanyada lösemi arttı: "Enerji açığı var” } \\
\text { iddiasına "Bu bir yalan” diye yanıt veren } \\
\text { EMO İstanbul şube başkanı İpek, “Termik, } \\
\text { hidrolik, rüzgar, güneş gibi kaynaklar doğru } \\
\text { projelendirilirse orta vadede sorun olmaz” dedi. } \\
\text { Dr. Sitkı Uyar Almanya’da lösemi vakalarında } \\
\text { artış gözlendiğini söyledi. }\end{array}$ & 1 \\
\hline $\begin{array}{l}12 \\
\text { Temmuz } \\
2000\end{array}$ & $\begin{array}{l}\text { Başlık: TAEK: Nükleer gerekli } \\
\text { Alt Başlık: Başbakan Ecevit’e } \\
\text { sunulmak üzere hazırlanan } \\
\text { raporda, toplumun nükleer } \\
\text { enerji konusunda yanlış } \\
\text { yönlendirildiği öne sürüldü. }\end{array}$ & $\begin{array}{l}\text { Türkiye Atom Enerjisi Kurumu’nun Başbakan } \\
\text { Bülent Ecevite ve kabine üyelerine sunulmak } \\
\text { üzere hazırladığı raporda, toplumun nükleer } \\
\text { enerji konusunda yanlış yönlendirildiği } \\
\text { vurgulanarak, "şu anda ülkemizde sahnelenen } \\
\text { senaryo budur" denildi. }\end{array}$ & 8 \\
\hline $\begin{array}{l}12 \\
\text { Temmuz } \\
2000\end{array}$ & $\begin{array}{l}\text { Başlık: İpek: Bu bir yalan } \\
\text { Alt Başlık: TAEK'in raporunu } \\
\text { eleştiren Elektrik Mühendisleri } \\
\text { Odası'na göre, enerji sorununun } \\
\text { başka çözümleri de var. }\end{array}$ & $\begin{array}{l}\text { Nükleer ihalesinin yaklaştığı şu günlerde, } \\
\text { TAEK'in Başbakan Bülent Ecevit’e sunulmak } \\
\text { üzere hazırlanan rapor çevreci bilim adamlarının } \\
\text { tepkisine neden oldu. Bilim adamları nükleer } \\
\text { santralların enerji açığının tek çözümü gibi } \\
\text { gösterilmesini eleştirdi. }\end{array}$ & 8 \\
\hline $\begin{array}{l}16 \\
\text { Temmuz } \\
2000\end{array}$ & $\begin{array}{l}\text { Başlık: Nükleere hayır şenliği } \\
\text { Alt Başlık: }\end{array}$ & $\begin{array}{l}\text { Mühendis ve mimar odaları, meslek birlikleri, } \\
\text { sendikalar, çevreci örgütler, siyasi partiler ve } \\
\text { demokratik kitle örgütlerinden oluşan Nükleer } \\
\text { Santrale Karşı Güç Birliği yarın 19.00'da Açık } \\
\text { hava Tiyatrosu'nda şenlik düzenliyor. }\end{array}$ & 3 \\
\hline $\begin{array}{l}22 \\
\text { Temmuz } \\
2000\end{array}$ & $\begin{array}{l}\text { Üst Başlık: ABD’li } \\
\text { konsorsiyumdan nükleer tehdit } \\
\text { Başlık: “Bir daha uzarsa } \\
\text { çekiliriz” } \\
\text { Alt Başlık: }\end{array}$ & $\begin{array}{l}\text { Yllan hikayesine dönem Akkuyu Nükleer } \\
\text { Santral ihalesinde son döneme girildi. ABD } \\
\text { konsorsiyumu, karar tarihi olan } 24 \text { Temmuz’da } \\
\text { da “uzatmaya” gidilmemesi halinde ihaleden } \\
\text { çekileceklerini açıkladı. }\end{array}$ & 18 \\
\hline $\begin{array}{l}22 \\
\text { Temmuz } \\
2000\end{array}$ & $\begin{array}{l}\text { Başlık: Nükleere karşı tam } 80 \\
\text { bin imza } \\
\text { Alt Başlık: }\end{array}$ & $\begin{array}{l}\text { İzmir'de } 51 \text { sivil toplum örgütünün katılımıyla } \\
\text { oluşturulan "Nükleer Santrallara Karşı İzmir Güç } \\
\text { Birliği Platformu" dün bir basın açıklaması yaptı. }\end{array}$ & 18 \\
\hline $\begin{array}{l}24 \\
\text { Temmuz } \\
2000\end{array}$ & $\begin{array}{l}\text { Başlık: Nükleer içime sinmedi } \\
\text { Alt Başlık: Ecevit: Santral } \\
\text { ihalesinin iptal edebiliriz }\end{array}$ & $\begin{array}{l}\text { Başbakan karar günü öncesi Milliyet’e konuştu: } \\
\text { Endişeliyiz. Dünya bu teknolojiyi artık terk } \\
\text { ediyor. }\end{array}$ & 1 \\
\hline $\begin{array}{l}25 \\
\text { Temmuz } \\
2000\end{array}$ & $\begin{array}{l}\text { Başlık: Nükleer karar günü } \\
\text { Alt Başlık: Nükleer karar günü }\end{array}$ & $\begin{array}{l}\text { Başbakan Bülent Ecevit, uzatma süresi dün akşam } \\
\text { dolan Akkuyu’ya yapılması düşünülen nükleer } \\
\text { santral ihalesinin bugün görüşüleceği belirtildi. }\end{array}$ & 6 \\
\hline
\end{tabular}




\begin{tabular}{|c|c|c|c|}
\hline $\begin{array}{l}26 \\
\text { Temmuz } \\
2000\end{array}$ & $\begin{array}{l}\text { Başlık: Akkuyu kurtuldu } \\
\text { Alt Başlık: Hükümet nükleer } \\
\text { santral ihalesini dondurdu }\end{array}$ & $\begin{array}{l}\text { Milliyet'e “Nükleer santralı içime } \\
\text { sindiremiyorum» diyen Ecevit`e Bakanlar } \\
\text { Kurulu da katıldı. İşte karar: «Nükleer enerjiye } \\
\text { yönelmemiz gereksiz. Ekonomik açıdan da } \\
\text { sakıncalı." }\end{array}$ & 1 \\
\hline $\begin{array}{l}26 \\
\text { Temmuz } \\
2000\end{array}$ & $\begin{array}{l}\text { Başlık: Hükümet de sindiremedi } \\
\text { Alt Başlık: Nükleer santralı } \\
\text { içime sindiremiyorum diyen } \\
\text { Başbakan Ecevit’i Bakanlar } \\
\text { kurulu da destek verdi ve } \\
\text { nükleer santral ihalesi ertelendi. }\end{array}$ & $\begin{array}{l}\text { Nükleer santral ihalesinin bir süre ertelendiğini } \\
\text { açıklayan Başbakan Bülent Ecevit, "Doğalgaz } \\
\text { ve hidrolik santral yapımını kararlaştıran bir } \\
\text { ülke olarak diğer OECD ülkeleri gibi nükleer } \\
\text { enerjiye yönelmemiz şimdilik gereksiz. Ekonomik } \\
\text { açıdan da sakıncalı. Bu yüzden ekonomik istikrar } \\
\text { programımız ciddi olarak aksayabilir" dedi. }\end{array}$ & 4 \\
\hline $\begin{array}{l}26 \\
\text { Temmuz } \\
2000\end{array}$ & Başlık: İptale Milliyet katkısı & $\begin{array}{l}\text { "Nükleer santralın iptaline giden sürece Milliyet } \\
\text { damgasını vurdu. Gerek manşetleri, gerekse köşe } \\
\text { yazarlarıyla nükleer tehlikeye dikkat çekmek için } \\
\text { toplumu uyarma görevini yerini getirdi." }\end{array}$ & 4 \\
\hline
\end{tabular}

Tablo 2. Milliyet'te 11 Ocak 1999-26 Temmuz 2000 arasında yayımlanan köşe yazıları

\begin{tabular}{|c|c|c|c|}
\hline Tarih & Yazar adı & Yazının başlı̆ğ1 & Sayfa \\
\hline 14 Eylül 1999 & Fikri Sağlar & Akıllı olmak! & 16 \\
\hline 17 Eylül 1999 & Fikri Sağlar & Dost uyarıyor & 16 \\
\hline 21 Eylül 1999 & Fikri Sağlar & İhale ve ihanet! & 14 \\
\hline 26 Eylül 1999 & Fikret Bila & ABD gezisinde enerji dosyası & 16 \\
\hline 28 Eylül 1999 & Fikret Bila & Ecevitler'le uçakta sohbet & 14 \\
\hline 1 Ekim 1999 & Fikret Bila & Büyük pazarlık & 16 \\
\hline 14 Ekim 1999 & Fikret Bila & Ecevit'le sohbet & 14 \\
\hline 16 Ekim 1999 & Tunca Bengin & Ediz Hun uyarıyor & 23 \\
\hline 30 Ekim 1999 & Şahin Alpay & Greenpeace'in uyarısı & 22 \\
\hline 4 Aralık 1999 & Derya Sazak & Nükleer riski & 18 \\
\hline 8 Aralık 1999 & Melih Aş1k & Nükleer tezgâh... & 15 \\
\hline 25 Aralık 1999 & Melih Aşık & Danimarka örneği & 17 \\
\hline 26 Aralık 1999 & Meral Tamer & Nükleer ihale zor açıklanır & 6 \\
\hline 8 Ocak 2000 & Meral Tamer & Nükleersiz bayramlar & 6 \\
\hline 21 Ocak 2000 & Melih Aşık & Malum ucuz hikaye & 17 \\
\hline 29 Ocak 2000 & Doğan Heper & Elektrik kesintisi ayıbı... & 14 \\
\hline 2 Ocak 2000 & Meral Tamer & Nükleer Mantıksızlık & 8 \\
\hline 4 Şubat 2000 & Melih Aşık & Elektrik kaçağı & 8 \\
\hline 5 Şubat 2000 & Tunca Bengin & Nükleer komedi!... & 23 \\
\hline 10 Şubat 2000 & Meral Tamer & Nükleerde top Ecevit’te & 8 \\
\hline 3 Mart 2000 & Yalçın Doğan & Hesapta “nükleer güç" var... & 19 \\
\hline 5 Mart 2000 & Hasin Cemal & Kafam karışık, nükleer enerji konusunda... & 21 \\
\hline 9 Nisan 2000 & Fikret Bila & Nükleer ihale & 18 \\
\hline 9 Nisan 2000 & Meral Tamer & Enflasyon mu, nükleer mi? & 7 \\
\hline 20 Nisan 2000 & Meral Tamer & Nükleer macera iptal yolunda & 7 \\
\hline 23 Nisan 2000 & Derya Sazak & Tatlı bela & 20 \\
\hline
\end{tabular}


İNSAN\&İNSAN (6/21 YAZ/SUMMER 2019)

\begin{tabular}{|l|l|l|r|}
\hline 25 Mayıs 2000 & Fikret Bila & Nükleerde ABD atağı & 20 \\
\hline 17 Haziran 2000 & Meral Tamer & Dünya nükleerden dört nala kaçıyor & 7 \\
\hline 11 Temmuz 2000 & Güneri Cıvaoğlu & Karanlığın mesajı & 23 \\
\hline 22 Temmuz 2000 & Meral Tamer & "Nükleer: İptal etmek itibarımızı artırır" & 7 \\
\hline 24 Temmuz 2000 & Fikret Bila & Nükleere fren & 20 \\
\hline 25 Temmuz 2000 & Güneri Cıvaoğlu & Kalplerin sesi & 23 \\
\hline 25 Temmuz 2000 & Fikret Bila & Nükleer enerji & 20 \\
\hline
\end{tabular}




\title{
In the context of Gramsci's Theory of Hegemony the Representation of Anti Nuclear Movement in Milliyet Daily (January 11, 1999-July 25, 2000)
}

\author{
MEHMET ÖZÇAĞLAYAN / FİLIZZ YAVUZ ÇAKICI
}

\begin{abstract}
The Nuclear energy is a supra-governmental issue and a state policy. Therefore, although their political views were different, transitioning to nuclear energy by governments since the 1970s has been insisted. Contrarily, nuclear energy affects all people's lives. Hence, the success of Turkey's nuclear phase-in depends on the general public's consent. To provide it, the media emerges as an institution reproducing the dominant discourse. The article, having a conceptual base from Gramsci's theory of hegemony and using the discipline of Teun van Dijk's Critical Discourse Analysis, focuses on the representation of the anti-nuclear movement in the Milliyet Daily between January 11, 1999, when Bülent Ecevit became the Prime Minister, and July 25, 2000, when the Akkuyu Nuclear Power Plant bid was cancelled; and in this process, it was evaluated whether the Milliyet Daily produced the dominant discourse on nuclear energy and how and how much it fulfilled its responsibility towards society.
\end{abstract}

Keywords: Hegemony, Critical discourse analysis, Nuclear energy, Anti-nuclear movement, Milliyet Daily. 